\title{
Age and geodynamic evolution of the Black Sea Basin: tectonic evidences of rifting in Crimea
}

\author{
Jean-Claude Hippolyte ${ }^{1}$, Anna Murovskaya ${ }^{2}$, Yuri Volfman ${ }^{3}$, Tamara Yegorova ${ }^{2}$, Oleg Gintov², \\ Nuretdin Kaymakci ${ }^{4}$, Ercan Sangu ${ }^{5}$
}

\footnotetext{
1: Jean-Claude Hippolyte, Aix Marseille Univ, CNRS, IRD, INRA, Coll France, CEREGE UM34, Aix-en-Provence, France

2: Institute of Geophysics, National Academy of sciences of Ukraine, Pr. Palladina 32, Kiev 03680, Ukraine

Anna Murovskaya (murovskaya@gmail.com); Tamara Yegorova (egorova@igph.kiev.ua); Oleg Gintov (oleg.gintov@gmail.com)

3: Institute of Seismology and Geodynamics, Vernadskii Crimean Federal University, Republic of Crimea, St. Trubachenko, 23A, Simferopol 295048, Russia

Yuri Volfman (seism.volf@gmail.com)

${ }^{4}$ : Nuretdin Kaymakci, Middle East Technical University ODTU-METU, Department of Geological Engineering, 06800 Ankara, Turkey (kaymakci@metu.edu.tr)

${ }^{5}$ : Ercan Sangu Kocaeli University, Department of Geological Engineering, 41380, Kocaeli, Turkey (ercansangu@hotmail.com)
}

Key words: Fault; paleostress; graben; rifting; back arc basin; inversion; Black Sea; Crimea

\begin{abstract}
:
The timing and direction of opening of the Black Sea Basin are debated. However, parts of its margins were inverted during Cenozoic and can be studied onshore. The Crimean Mountains are located in the middle of the northern margin of the basin, and at the onshore prolongation of the mid-Black Sea High.

We present the first detailed mapping of large striated normal faults in Crimea. These faults define graben structures that trend parallel to the continental margin. Kinematic analysis of the faults combined with new biostratigraphic data show that the syn-rift sequence is Valanginian to Late Albian in age. It consists of siliciclastic deposits with limestone olistoliths. In contrast, the post-rift Late Cretaceous carbonaceous sequence of Crimea is devoid of normal faults or olistoliths. It unconformably overlies the graben structures.

The onset ages, and the trends of extension are quite similar in the northern (Crimea) and the southern (Turkey) inverted margins of the basin. The Early Cretaceous extension directions are normal to the mid-Black Sea High and the Black Sea margins. We conclude that rifting of Black Sea Basin occurred from the Valanginian to the Late Albian ( 39 Ma) and drifting during the Late Cretaceous.

Based on the directions of rifting, on the lack of evidence of strike slip motions near the mid-Black Sea High, and on published paleomagnetic data, we propose that the Black Sea opened with rotations accommodated by transform faults at its western and eastern margins, as a response to asymmetric slab rollbacks of the Neo-Tethys plate.

The inversion of the Crimean margin results from two successive shortening events: Early Eocene NE-SW compression, Eocene to Present SE-NW compression. Their timing support the idea that compressional stresses generated by continental collisions in Turkey were transmitted through the strong Black Sea lithosphere up to Crimea.
\end{abstract}




\section{1-Introduction:}

The Black Sea is a $2200 \mathrm{~m}$ deep marine basin surrounded by alpine mountains including the Balkanides, the Pontides, the Greater Caucasus and the Crimean Mountains (Fig. 1A). Because of its location, at the rear of the Srednegorie-Pontides-Achara-Trialet magmatic arc, it is classically interpreted as a back arc basin that opened from Cretaceous to Paleocene times within the East European platform, behind the north-dipping Neotethyan subduction zone (e.g. Zonenshain and Le Pichon 1986; Finetti et al., 1988; Dercourt et al., 1993; Okay et al., 1994; Robinson et al., 1996; Nikishin et al., 2003; Barrier and Vrielynk, 2008). Deep seismic reflection data show that it is composed of two large deep sub-basins, the Western Black Sea Basin and the Eastern Black Sea Basin, separated by the mid-Black Sea High which consists of the Andrusov and Archangelsky ridges (Fig. 1) (Tugolesov et al., 1985; Finetti et al., 1988; Manetti et al., 1988; Robinson et al., 1996; Starostenko et al., 2004; Afanasenkov et al., 2007; Shillington et al., 2008; Yegorova and Gobarenko, 2010; Nikishin et al., 2011; Graham et al., 2013; Yegorova et al., 2013; Nikishin et al., 2015a; 2015b). Their basement probably includes thinned continental crust and oceanic crust but there are no magnetic stripes to corroborate this interpretation (e.g. Belousov et al., 1988; Finetti et al., 1988; Yegorova et al., 2010; Yegorova et al., 2013; Graham et al., 2013). Seismic refraction data shows $\sim 40-\mathrm{km}$ thick continental crust of the Scythian Plate (Neoproterozoic basement) and the East European Platform (Archaen-Palaeoproterozoic basement; Saintot et al., 2006b; Okay and Nikishin, 2015), and thin oceanic or/and continental crust in the Western Black Sea Basin (Yegorova et al., 2010; Baranova et al., 2011). The Andrusov ridge is underlain by continental crust up to 28-29 km thick (e.g. Shillington et al., 2009; Yegorova et al., 2010).

Although it is located in an oil-rich part of the world, the prospectivity of the Black Sea Basin is poorly known (e.g. Graham et al., 2013). Even the age of rifting of the sub-basins is still an unsolved issue. Rifting occurred either during the Early to Middle Cretaceous (e.g. Görür, 1988) or during the Late Cretaceous (e.g. Tüysüz et al., 2012). The abyssal plain is underlain by up to $14 \mathrm{~km}$ thick Mesozoic and Cenozoic post-rift sedimentary sequences (e.g. Yegorova and Gobarenko, 2010; Graham et al., 2013) and the lower seismic units have not been drilled and dated (e.g. Nikishin et al., 2015a).

Because the offshore stratigraphy is often speculative, onshore studies around the Black Sea are of prime importance for understanding the evolution of the Black Sea Basin and its petroleum potential. Seismic lines show that Cretaceous graben structures have been inverted around the Black Sea Basin (Munteanu et al., 2011; Espurt et al., 2014), and structural mapping in the Pontides shows that such inverted grabens can be studied onshore (Hippolyte et al., 2010; 2016).

The Crimea Peninsula is located in the central part of the northern Black Sea margin, and at the western continuation of the Eastern Black Sea Basin and mid-Black Sea High (Fig. 1). Moreover, the Crimean Mountains allow the study of an almost complete stratigraphic sequence of the Black Sea margin (e.g. Nikishin et al., 2017). To constrain the timing of Black Sea rifting we carried out structural mapping and fault kinematic analyses in the Crimean Mountains. In this paper, we report the discovery of large normal faults with preserved striation in southwestern Crimea. We provide new kinematic data and age constrains for understanding the geodynamic evolution of the Black Sea Basin.

\section{2- Geological setting of the Black Sea \\ 2.1- Plate tectonic setting}

The Black Sea area recorded a complex evolution from subduction to collisions during the closure of the Neo-Tethys Ocean (Zonenshain and Le Pichon, 1986; Dercourt et al., 1986; Finetti et al., 1988; Robinson et al., 1996; Nikishin et al., 1998; 2017; Kaymakci et al., 2003a; Barrier and Vrielynck, 2008). In Triassic time, the oceanic plate width between Gondwana and Laurasia was about $2000 \mathrm{~km}$ at the south of the future Pontides (Barrier and Vrielynck, 2008). The northward subduction of the Neo-Tethys oceanic plate under the Eurasian continental plate lasted at least for 
120 million years (Norian to Campanian; e.g. Barrier and Vrielynck, 2008; Sosson et al., 2016). It generated arc-type magmatic products from Moesia in the west to the Lesser Caucasus in the east (Fig. 1A; Adamia et al., 1981; Lordkipanidze et al., 1989; Robinson et al., 1996; Meijers et al., 2010b; Okay and Nikishin, 2015). In this context, the Black Sea Basin opened in a back arc setting during the Cretaceous and/or Cenozoic (e.g. Zonenshain and Le Pichon, 1986).

During Cenozoic time, several continental plates collided along the southern margin of Eurasia (Kirshehir Block, Taurides-Anatolides-South Armenia Block, Arabian Plate; Fig. 1A) (Kaymakci et al., 2003a). Compressional stresses resulted in the structural inversion of large parts of the Black Sea margins mainly during the Eocene and the Oligocene (eg. Kaymakci et al., 2003a, 2003b, 2009; Dinu et al., 2005; Saintot et al., 2006a; Bergerat et al., 2010; Munteanu et al. 2011; Espurt et al., 2014; Vincent et al., 2016; 2018; Hippolyte et al., 2017). The suture zone of the NeoTethys Ocean is marked by an ophiolite belt and subduction-accretion complex, the Izmir-AnkaraErzincan suture (Fig. 1A), running from Izmir on the Turkish coast, through Ankara, into the Sevan region of Armenia (Okay and Tüysüz, 1999).

\section{2- Mechanism of the Black Sea opening}

Whereas there is a general agreement that the Black Sea opened as a back arc basin, the mechanism and direction of opening of its sub-basins are still unclear. Various conceptual models have been proposed. The Eastern Black Sea Basin either opened during clockwise rotation of the mid-Black Sea High (Robinson et al., 1996; Shillington et al., 2009), or because of a counterclockwise rotation of the east Black Sea block accompanied by subduction beneath the Greater Caucasus (Okay et al., 1994). The Western Black Sea Basin is supposed to have opened during a southward drift of a continental block (Istanbul zone) along one, or two transform faults. A dextral transform fault, located at the western margin of the Black Sea Basin, is invoked in many models (Okay et al., 1994; Robinson et al. 1996; Nikishin et al., 2003; 2011, 2015b). The motion along this fault probably caused the dextral offset of the Late Cretaceous Srednogorie and Western Pontides magmatic arc (Fig. 1A; Nikishin et al., 2011). Depending on the model, a sinistral transform fault at the eastern border of the southward drifting block, is placed either to the west of Crimea and within the Western Black Sea Basin (West Crimean Fault; Okay et al., 1994), or closer to southwestern Crimea and along the southern edge of mid-Black Sea High (Robinson et al., 1995, 1996; Cloetingh et al., 2003; Yegorova and Gobarenko, 2010; Graham et al., 2013). Models that do not implicate sinistral transform faults have also been proposed. In this case, the opening of the two sub-basins was achieved by asymmetric back-arc extension with counterclockwise rotation of the Pontides caused by asymmetric trench retreat (Nikishin et al., 2003; 2011; Stephenson and Schellart, 2010). In summary, the main difference between all these models is the presence or absence of left lateral displacement along the southern border of the mid-Black Sea High and along the continental margin offshore southwestern Crimea (Fig. 1). This issue can be addressed by paleostress analyses in Crimea, which is one of the goals of our study.

\section{3- Age of the Black Sea rifting}

Based on stratigraphic studies in the Central Pontides (Turkey), in Romania and in the Crimean Mountains, most authors concluded that the rifting of the Black Sea Basin occurred during the Early to Middle Cretaceous (Barremian or Aptian-Albian-Cenomanian; e.g. Finetti et al., 1988; Görür, 1988; 1997; Manetti et al., 1988; Görür et al., 1993; Okay et al., 1994; Robinson et al., 1995, 1996; Nikishin et al., 2003; 2011, 2017; Dinu et al., 2005; Hippolyte et al., 2010; Munteanu et al., 2011). The rifting of the Eastern Black Sea Basin was supposed to have occurred during the same period (Aptian-Albian, Nikishin et al., 2003; 2011; Albian to Santonian; Bektaş et al., 1995; Eren and Tasli, 2002), or later, during the Paleocene (e.g. Finetti et al., 1988; Robinson et al., 1995, 1996; Spadini et al., 1996; Shillington et al., 2008). 
The Early Cretaceous age of rifting was initially constrained by two sets of stratigraphic data in the Central Pontides (Turkey): (1) the deposition of terrigenous material on Jurassic carbonates. It was interpreted as a marker of disintegration of the carbonate platform that developed on the south-facing continental margin of Eurasia during the Late Jurassic (Görür, 1988); (2) a drastic change in sedimentation from dark terrigenous sediments (Çağlayan Group), to red pelagic limestones (Kapanboğazı Formation) deposited in a strongly oxic environment of 500-1000 m water depth. It was interpreted as marking the end of anoxia (Görür et al., 1993; Görür, 1997). Görür et al. (1993) proposed that the unconformity between the Çağlayan and the Kapanboğazı Formations was the break-up unconformity separating the syn-rift and post-rift sequences. Similarly, in Crimea, the Albian-Cenomanian transition was considered as the time of crustal separation (Nikishin et al., 2003; 2011).

But the stratigraphic position and the significance of the post-rift transition are debated. In the Central Pontides we found that the Late Cenomanian break-up unconformity defined by Görür et al. (1993) is locally an angular unconformity with a stratigraphic gap from the Upper Albian to the Coniacian (Hippolyte et al., 2010). This angular unconformity indicates Late Albian tectonic uplift and erosion that results either from rift flank thermal uplift as suggested for a thick lithosphere (Robinson et al., 1995; Spadini et al., 1996; Cloetingh et al., 2003), or from continental collision, as suggested by Aptian-Albian metamorphic ages in the Central Pontides (Okay et al., 2006, 2013, Hippolyte et al., 2017). Note that in the Eastern Pontides, hiatuses of the latest Kimmeridgian to Berriasian and Hauterivian to Barremian were also interpreted as evidences of rift flank uplift during regional extension (Vincent et al., 2018).

Considering that back arc rifting should be contemporaneous with arc magmatism, and that in northern Turkey the Middle Turonian-Early Santonian Dereköy Formation (Tokay, 1952) contains the oldest voluminous Cretaceous volcanogenic rocks, Tüysüz (1999) and Tüysüz et al. (2012) proposed an onset of rifting during the Cenomanian-Santonian, and continental break-up during the Late Santonian. In addition, detrital zircons in Lower Cretaceous turbidites of Central Pontides that were probably derived from the Ukrainian shield, suggested that there was no thoroughgoing Black Sea Basin between the Pontides and the East European Craton during the Early Cretaceous (Okay et al., 2013; Akdoğan et al., 2017).

However, based on seismic profiles and on a revised stratigraphy of well data, Khriachtchevskaia et al. (2010) proposed an Aptian to Santonian age for rift structures of the northern margin of the Black Sea (Karkinit Trough, North Azov Trough...) and concluded that rifting of the Black Sea began not latter than Aptian-Albian times. Similarly, in the Greater Caucasus, Late Tithonian to Berriasian and Hauterivian to Early Aptian episodes of subsidence were tentatively linked to initial rifting within the Black Sea (Vincent et al., 2016).

Finally, Okay et al. (2013) proposed that an Early Cretaceous non-volcanic rifting and a Late Cretaceous (Turonian-Santonian) opening of the Black Sea are unrelated events. In addition, Nikishin et al. (2015b) proposed that one rifting event predating the Cenomanian occurred outside the Eastern and Western Black Sea basins, and that later, during Cenomanian-Early Santonian time, the main phase of rifting and spreading concentrated in the Eastern and Western Black Sea basins. They distinguished two main rift/post-rift regional unconformities in Crimea, one between the Albian and the Cenomanian, and one within the Santonian (Nikishin et al., 2017). They agreed with Tüysüz et al. (2012) to draw the regional rift/post-rift boundary within the middle Santonian and to place the main phase of rifting and spreading of oceanic crust during Cenomanian-Early Santonian time (Nikishin et al., 2017; Tüyzüz, 2017).

In fact, subduction related volcanic activity is now attested before the Middle Turonian. In southwestern Crimea, Nikishin et al. (2013) confirmed the Late Albian age of calc-alkaline volcaniclastic sandstones. Albian volcanoes are also known within the Odessa Shelf, the Crimea Lowland, and the Karkinit graben (Gozhik et al., 2006; Afanasenkov et al., 2007; Nikishin et al., 
2015a). In addition, it is noteworthy that in this debate, the distinction between syn-rift and post-rift sequences is rarely supported by structural data.

Structural mapping showed that large extensional deformation occurred from the Barremian to the Albian in the Western Pontides (Hippolyte et al., 2010), and in the Central Pontides (Espurt et al., 2014; Hippolyte et al., 2016). This stretching event was characterized by the emplacement of large olistoliths in the terrigenous Early Cretaceous sequence. In contrast, only minor extensional faults were found in the Santonian to Paleocene rocks (Hippolyte et al., 2010; 2016).

In Crimea, the Early Cretaceous sequence also consists of terrigenous rocks (shales, sandstone and conglomerates) with limestone olistoliths. It was concluded from stratigraphic studies, and in particular from the observation of olistoliths and debris flow deposits, that vertical movements caused by several pulses of rifting occurred during the Barremian-Albian (Nikishin et al., 2008; 2017).

To check if the Early Cretaceous extensional block faulting event, previously identified along the southern margin of the Black Sea (Hippolyte et al., 2010; 2016), is related to the opening of the Black Sea, or to different geodynamic processes (e.g. Okay et al., 2013), we need to compare the structural evolution of the two conjugate margins of the Black Sea Basin.

\section{3- The Crimean Mountains}

The Crimean Mountains are located at the southeastern margin of the Crimean Peninsula, in a key area for understanding the opening of the Black Sea Basins (Fig. 1A). They border the western edge of the Eastern Black Sea Basin, and are close to the northern margin of the Western Black Sea Basin. Southwestern Crimea is also located at the western prolongation of the mid-Black Sea High. Thereby, tectonic deformation of this area may have recorded the opening of the two Black Sea sub-basins before Cenozoic tectonic inversion.

\section{1- Age and structure of the Crimean Mountains}

The Crimean Mountains form the westernmost prolongation of the Crimea-Greater Caucasus orogenic belt (Fig. 1A). This orogenic belt is bordered by flexural foredeep basins including the Sorokin Trough and the Tuapse Trough to the south, and the Indolo-Kunban Trough to the north (e.g. Sydorenko et al., 2017; Nikishin et al., 2017). These basins are mainly filled with Oligocene-Lower Miocene (Maykopian) sediments (Finetti et al., 1988; Robinson et al., 1996; Nikishin et al., 2015a, b; Sydorenko et al., 2017). As they initiated as a flexural response to crustal scale thickening, the age of their sedimentary infill should correspond to periods of compressional uplift of the adjacent mountains (e.g. Vincent et al., 2007; 2016; Nikishin et al., 2010; Sheremet et al., 2016b; Sydorenko et al., 2017). Offshore Crimea, the Sorokin Trough is mainly filled with up to $>5 \mathrm{~km}$ of clay-rich Maykopian sediments, overlain by Middle Miocene and younger strata (Sydorenko et al., 2017). It started to subside at the Eocene-Oligocene boundary (Nikishin et al., 2017; Sydorenko et al., 2017), or during the Paleocene (Sheremet et al., 2016b). It was inferred that compressional tectonics in the Crimean Mountains possibly started as early as the Eocene (Nikishin et al., 2017; Sydorenko et al., 2017), or the Paleocene (Sheremet et al., 2016b). Apatite fission track ages $(50.6 \pm 4.7-32.2 \pm 1.8 \mathrm{Ma})$, and modelled time-temperature paths (Panek et al., 2009), indicate an Eocene-Early Oligocene exhumation of the Crimean Mountains. Nonetheless, based on the stratigraphic sequences, there is a large agreement that the main phase of compression occurred during the Oligocene-Miocene in the Crimean Mountains like in the Western Caucasus (e.g. Vincent et al., 2007; Nikishin et al., 2010; 2015; Sheremet et al., 2016b; Sydorenko et al., 2017).

No consensus exists about the structure of the Crimean Mountains. Whereas Muratov (1969) assumed no significant horizontal movements, Yudin $(1993,2009)$ proposed that these mountains are constituted by multiple thrust sheets with tectonic melanges and olistostromes. On two sections across the eastern part of Crimean Mountains and the Sorokin Trough, Sheremet et al. (2016b) also 
showed mainly south-vergent thrusts. They indicated that normal faults identified on seismic lines, are related to the subsidence of the foreland basin, and not to Eastern Black Sea rifting.

At a large scale, the Crimean Mountains appears as a large monocline dipping to the northwest that results from an about $5^{\circ}$ post-Eocene northward tilting (Fig. 2; e.g. Meijers et al., 2010b). The seismic activity, focal plane mechanisms and fault kinematic analyses indicate that compressional deformation is still going on (Angelier et al., 1994; Saintot et al., 1998; Saintot and Angelier, 2000; Gintov, 2005; Gobarenko et al., 2016; Murovskaya et al., 2016). Because of this northwestward tilting, the highest mountains of Crimea are present along its southeastern coast (Fig. 2). Elevations do not exceed 1545 m (Roman Kosh, in southwestern Crimea; Fig. 2). The southern narrow slope of the Crimean Mountains frequently corresponds to the edge of limestone plateaus with high cliffs where the sedimentary pile is well exposed.

\section{2- Stratigraphy of the Crimean Mountains}

The oldest rocks exposed in Crimea, belong to the Tauric Complex, attributed to the Upper Triassic-Lower Liassic (e.g. Nikishin et al, 2017; Oszczypko et al., 2017). They include deep-water terrigenous flysch deposits similar to deposits of the Küre Complex in the Central Pontides (Ustaömer and Robertson 1994; Nikishin et al., 2011). In the eastern Crimean Mountains, formations mapped as Tauric Complex (Muratov, 1969) have been dated as Early Cretaceous in age (Popadyuk and Smirnov, 1991; Popadyuk et al., 2013; Sheremet et al., 2016a; Oszczypko et al., 2017). The age of this complex is still the subject of debate (e.g. Nikishin et al., 2017; Oszczypko et al., 2017), but it does not concern our study area in southwestern Crimea where the Tauric Complex is stratigraphically overlain by Jurassic rocks (Fig. 2).

The middle Jurassic sequence includes isotopically dated Bajocian volcanic rocks (Meijers et al., 2010b) that belong to a volcanic arc that was active during the Aalenian to Bajocian main phase of rifting of the Greater Caucasus Basin (Vincent et al., 2016). In Eastern Crimea, Tithonian to Berriasian subduction-related volcanic rocks provide evidence for Jurassic northwards subduction below the Eurasian margin, preceding the opening of the Black Sea Basin (Meijers et al., 2010b). In western Crimea, the Late Jurassic time was characterized by deposition of thick carbonates and conglomerates series. Now, these Kimmeridgian-Lower Berriasian units form the main cliffs along the southeastern coast of Crimea.

Starting from the Late Berriasian or Valanginian (e.g. Nikishin et al., 2017), sedimentation changed markedly with the deposition of terrigenous sediments (Fig. 2). The Early Cretaceous series include Valanginian-Hauterivian clays, marls and sandstones, Upper Hauterivian-Lower Barremian limestones and sandstones, Upper Barremian-Aptian clays with siderite nodules, middle and Upper Albian sandstone and volcanic tuff (e.g. Nikishin et al, 2017). In contrast with these units, the Cenomanian-Thanetian sequence mainly consists of shelf-type deposits. The Late Cretaceous series includes Cenomanian-Coniacian limestones and Santonian-Maastrichtian marls (e.g. Nikishin et al, 2017). A limestone sequence covered by marls characterized both the Paleocene and the Eocene units (Fig. 2). They form two distinctive cuestas along the northern slope of the Crimean Mountains (Fig. 2; e.g. Muratov, 1969; Yudin, 2009; Nikishin et al, 2017). Middle and Upper Miocene shallow marine deposits (limestone sandstone and clays) cover the low lands of Crimea.

Based on stratigraphic unconformities, several tectonic events have been proposed for the formation of the Crimean Mountains (Muratov, 1969; Sheremet et al., 2016b; Nikishin et al., 2017). However, they are not all angular unconformities, and generally, they have not been related to tectonic structures. Orogenic events are inferred for the Triassic-Jurassic and Early-Middle Jurassic boundaries, and during the deposition of the Oligocene-Quaternary sediments (Muratov, 1969; Nikishin et al., 2017). A regional unconformity also marks the base of Ypresian-Lutetian deposits (Fig. 2; Nikishin et al., 2017). Syn-rift series would include Callovian-Oxfordian, and Late Barremian-Albian sediments (Nikishin et al., 2017). Whereas postrift sequences, would include 
Kimmeridgian-Berriasian and Cenomanian-Lower Santonian sediments (Nikishin et al., 2017). Concerning the Early Cretaceous, extensional tectonics was mainly inferred from the presence of olistoliths and olistostromes (e.g. Nikishin et al., 2017). However, this argument is not decisive because olistoliths and olistostromes are mass-transport deposits that can be found in both extensional and compressional tectonic settings. For example, they are frequently related to nappe emplacement in syn-orogenic environments (e.g. Golonka et al., 2015). To check if the olistoliths of Crimea are related to normal faulting, or to compressional deformation, we carried out structural analyses in southern Crimea.

\section{4- Structural analysis of southern Crimea:}

Various geological maps of Crimea have been produced over time (e.g. Muratov, 1969; Yudin, 2009; Popadyuk et al., 2013; Bilecki, 2006; http://geoinf.kiev.ua/wp/kartograma.htm; http://webmapget.vsegei.ru/index.html). Whereas there is an agreement on the mapping of the Late Cretaceous-Neogene rocks, that form a monocline dipping to the Northwest, strong discrepancies exist concerning the fault traces and the distribution and age of the older rocks. Muratov (1969), produced the first 1/200 000 scale geological maps based on extensive biostratigraphic studies and detailed mapping of sedimentary units. They are often considered as of good accuracy (e.g. Popadyuk et al., 2013). In figure 2, we present a geological map, which is modified from Muratov's maps (1969) and Yudin (2009) using google satellite images and our field mapping in southeastern Crimea. We distinguish six unconformities in the Jurassic-Miocene units (Fig. 2). Note that the Oligocene-Eocene unconformity (e.g. Nikishin et al., 2017) is only mapped in eastern Crimean Mountains where shales of the Maykopian Group are exposed. The Lower Miocene and the Eocene-Paleocene unconformities are erosional surfaces, separating rock masses of various ages, which we interpret as the result of orogenic activity.

The joint use of geological maps, satellite images and SRTM 1s DEM, permitted a 3D structural analysis of the Crimean Mountains. We could identify and map normal faults mainly in the southeastern part of the Crimean Mountains (Fig. 3; Hippolyte et al. 2014). We studied these faults in the field in particular to check if they are normal faults, and to measure their slip direction. We also carried out paleostress analyses along these faults to understand the geodynamic evolution of Crimea. A previous paleostress study in Crimea and Greater Caucasus, by Saintot et al. (1998), concluded for six Cenozoic tectonic events, but did not show the Cretaceous rifting. We determined paleostresses from inversion of fault slip data with the INVD method (Angelier et al., 1990). We used slickenside superposition and fracturing analysis to unravel the chronology of extensional and compressional tectonic events. We will describe the main extensional structures checked during fieldwork.

\section{1- Honcharne (Goncharnoe) half graben.}

According to Muratov (1969), the plain around Honcharne village (formerly named Varnutka village) is underlain by greenish clays, marls and sandstones of Valanginian-Hauterivian age and clays with siderite nodules of Late Barremian-Aptian age. A fault is mapped at the foot of a hill bordering the Honcharne plain to the north (Muratov, 1969), and was partly studied by Saintot et al. (1998) and Gintov (2005). Road cuts allow the observation of the fault plane at two places (sites Var1 and Var2, Figs. 3, 4, 5). At the eastern site (Var1, Figs. 3 and 4), we found a northwest dipping fault surface separating Late Jurassic limestone of the foot-wall block from Cretaceous greenish clays of the hanging-wall block (Fig. 4, Hippolyte et al 2014). Large grooves clearly show that it is a dip-slip normal fault (Fig. 4D). Nannoplankton assemblages from samples 19 and 20 indicate a Valanginian age for the greenish clays (Figs. 4A, 4B and 4C). At the western site (Var2, Figs. 3 and 5), nannoplankton assemblages from sample 21 indicate an Early Barremian age for greenish clays with quartz sandstones intercalations (Table1). Consequently, the ValangianHauterivian formation of Muratov (1969) is dated here as Valanginian-Early Barremian. 
Limestone olistoliths along the fault plane suggest that rock falls from a limestone scarp occurred during the Early Cretaceous (Fig. 4B). At sites Var1 and Var2 (Fig. 5B), the intercalations of limestone debris flow deposits in the terrigenous Early Cretaceous sediments also suggests that erosion of the uplifted foot-wall block occurred during Valanginian to Barremian time. We conclude that normal faulting created fault scarps during the infill of the Honcharne basin, and that syn-depositional extension occurred from the Valanginian to the Barremian.

At site Var2, the fault surface also shows large normal striations. Locally horizontal striations (not present at site Var1) reveal a minor reactivation of the fault in a dextral sense. The chronology of the fault striations is clear. Given the fact that tiny horizontal striations are superimposed on the sides of the large dip-slip corrugations, we infer that they have formed after the Cretaceous normal slip. Fault slip analyses at sites Var1 and Var2 show that the Early Cretaceous trend of extension was NNE-SSW along the Honcharne fault (Figs. 4A and 5C). Slickenside superposition, indicate that two compressional events with NE-SW and NW-SE trends postdate the extension. We conclude that despite a minor strike-slip reactivation, the Honcharne fault is a well-preserved NW-trending Cretaceous normal fault that moved in response to NNEtrending extension. Normal faulting controlled the infill of the Honcharne half graben. Therefore, extensional deformation is attested at least from Valanginian to Barremian time in this area.

\section{2- Kyzylove half graben}

Immediately south of Kyzylove village (Fig. 3), a fault is drawn on Muratov's map (1969). It separates clays and sandstone from Jurassic limestones (Fig. 6A), but Muratov (1969) mapped these two sequences as Tithonian. We could map the Kyzylove fault as $4.5 \mathrm{~km}$ long. The fault extends southeastward near the Black Sea coast. There, the steep southern slope of the mountain allows the study of the fault zone in cross-section (Fig. 6D). The fault dips about $60^{\circ}$ to the northeast. The fault contact is clear between the Jurassic limestones and the flysch like deposits with dense forest cover (Fig. 6D). The touristic Foros church was built at the top of the Jurassic limestone of the hanging-wall block, at $400 \mathrm{~m}$ elevation. In the footwall block, the uppermost Kimmeridgian limestone is at $657 \mathrm{~m}$ elevation. We infer for the Kyzylove normal fault, a minimum vertical throw of $257 \mathrm{~m}$, and a net slip over $290 \mathrm{~m}$ (Fig. 6D).

Thanks to a landslide perpendicular to the fault (dashed line in Fig. 6D), the southern tip of the fault zone can studied in cross-section. The fault zone in the Jurassic limestone includes several large fault surfaces parallel and immediately west of the main fault contact (footwall block; Fig. 6D). We could measure the main striated faults surfaces and determine their sense of slip by using calcite steps as kinematic indicators. The large north-dipping fault planes are normal fault with dipslip striation (Fig. 6C). Minor conjugate normal faults are also present which allows computation of a NE-trending extension (Fig. 6D). Slickensides superposition moreover indicates that many of the NE-dipping normal faults were reactivated as dextral-reverse faults during NNE-trending compression (Fig. 6D). This fault chronology is consistent with that deduced from the Honcharne half graben (Fig. 4A).

We also measured striated normal fault surfaces in the hanging-wall block, at a site located immediately east of Foros church (Fig. 6D). As in the fault zone, they indicate NE-trending extension (fault diagram Cr15 in Fig. 3).

Classically, along normal faults, the younger sedimentary units are found on the hangingwall block. The Kyzylove village is on the hanging-wall block (Fig. 6A). Around this village, the rocks are greenish clays alternating with beds of sandstone, with frequent grass and forest cover (Figs. 6A and 6B). Whereas Muratov (1969) mapped them as Tithonian, our two samples from these clastic rocks yielded Early Cretaceous ages in agreement with the normal slip of the fault. Sample 35, from flysch like deposits outcropping just $\sim 30 \mathrm{~m}$ above the Kimmeridgian-Lower Berriasian limestone of Foros church, yielded nannoplankton assemblages of the ValanginianHauterivian (Fig. 6D; Table 1). Sample 34, from sandy clays upper in the sequence, yielded a Late 
Aptian age (Table 1). We infer that the greenish clays and sandstones filling the Kyzylove and the Honcharne half grabens are of the same age: Valanginian to Aptian.

A large olistolith of Jurassic limestone is exposed in the Kyzylove Cretaceous basin at 900 meters from the normal fault (Fig. 6A). This limestone olistolith confirms that the deposition of the terrigenous Early Cretaceous sequence postdates the Tithonian carbonates. As for the Honcharne basin, it supports the idea that the Kyzylove half graben was filled during normal faulting, that generated gravitational instability along a fault scarp. We conclude that the Honcharne basin and the Kyzylove basin are half grabens formed by NNE to NE-trending extension at least from Valanginian to Late Aptian time. Note that at Foros, the base of the synrift fill of the grabens is exposed. The Valanginian age of sample 35 (stratigraphically $\sim 30 \mathrm{~m}$ above the top of the Kimmeridgian-Lower Berriasian limestone), agrees with the oldest ages of the Lower Cretaceous shales in Crimea (e.g. Nikishin at el., 2017). We infer from the oldest age of the infill that rifting started during the Valanginian, but a Late Berriasian onset is not excluded.

\section{3- Cretaceous submarine scarps}

The two graben structures described above are the first kilometer-scale extensional structures described in the Cretaceous sequences of Crimea. In their study of a large Albian olistostrome, Nikishin et al. (2017) also reported two surfaces of normal faults in the quarries around Balaklava (Fig. 3). We believe that the main reason why normal fault contacts have rarely been observed is that the steep contacts between Early Cretaceous rocks and their Jurassic basement are often of erosional nature. In Muratov's model (1960; 1969), the Lower Cretaceous marine sediments filled depressions made by river erosion whose location was determined by faults or zones of fracturing. In his model, the Lower Cretaceous marine flooding was so fast that the erosional topography was preserved and buried under clayey sediments.

According to Muratov (1969), the Upper Barremian-Aptian clays outcropping near Balaklava fill such paleo-valleys (Fig. 3). The onlap unconformity, between the Cretaceous clays and the Jurassic limestone, is exposed in Gasforta quarry situated at the foot of a limestone ridge (Fig. 7A). Note that this quarry is located to the east of Balaklava city where Nikishin et al. (2011, 2013, 2015a) described the "Balaklava Graben" as an about 100 m thick infill of Aptian and Albian shales, debris flow deposits and olistostromes.

In Gasforta quarry, there is no visible fault contact between the Cretaceous clays and the Jurassic limestone. This limestone dips $40^{\circ}$ to the north, and the clays onlap a southwest dipping paleo-scarp (Fig. 7A). This stratigraphic onlap seems in agreement with Muratov's interpretations of paleovalleys. An iron-rich crust (probably made by microbialites) covers the limestone paleoscarp surface (Fig. 7A). Marine fossils are stuck on this iron crust. They include crinoid stem fragments and sea urchin's spines (Fig. 7B). We infer that the paleo-scarp was a Cretaceous submarine scarp that was later onlapped by the Barremian-Aptian clays.

Fracture analysis provides clues for understanding the origin of this NW-trending submarine scarp. Both extensional and compressional faults are present in the Jurassic limestone along the scarp (cf. fault diagrams in figure 7D). Inversion of the fault slip data indicates two shortening events with maximum compressional stress axes trending NE-SW and NW-SE. They correspond to the shortening events identified along the Honcharne and Kysylove faults (Figs. 4A, 5C and 6D). They can explain the northward dip of the rocks. Extensional faults are also present. They trend ESE-WSW and predate the folding (Fig. 7D). The chronology of faulting is indicated by the tilt of the normal faults and by their reactivation as strike-slip faults during compression (Fig. 7D). The sketches of figure 7D show the evolution of the scarp during extensional and compressional events. In the second fault diagrams of figure 7D, we have rotated the normal faults back to their original attitude, when bedding was horizontal. It shows that the Cretaceous extension was trending NE-SW (Fig. 7D) as we found for the Honcharne and Kyzylove half grabens. 
The fact that the paleo-scarp of the Gasforta quarry trends parallel to the normal faults suggests that it was primarily generated by normal faulting. In addition, the lack of striation on the paleo-scarp surface suggests that the main striated fault surface has been eroded. Along the limestone scarp, we found sedimentary dykes, which are open fractures filled by Cretaceous marine sediments (Fig. 7A and 7C). Moreover, olistoliths and debris flow deposits are frequent in the Early Cretaceous sequence. Therefore, Cretaceous gravitational erosion of a large submarine fault scarp can explain the lack of striated fault surface, and the sedimentary dykes at Gasforta quarry (Fig. 7D step 2). More generally, gravitational sliding and rock falls from the fault scarps probably provided the limestone olistoliths and debris that are frequent in the basin (Fig. 3). We propose that a combination of normal faulting and gravitational erosion generated this Cretaceous scarp. The cracks opened in the Cretaceous sea either during normal faulting or during gravitational sliding.

Our structural analysis at Gasforta quarry suggests that the deposition of Early Cretaceous sediments at lower elevation than the Late Jurassic carbonates in Crimea, results from tectonic subsidence and not from Cretaceous river erosion as proposed by Muratov (1960; 1969). The Honcharne and Kyzylove half grabens clearly demonstrate that tectonic subsidence occurred during the Early Cretaceous. Paradoxically, we can explain the lack of evidences of normal faults in Crimea by large extensional deformation. In southwestern Crimea, the Early Cretaceous tectonic subsidence was faster than sedimentation, as to produce submarine fault scarps within an underfilled basin. Underfilled basins occur when subsidence dominates. In underfilled faulted basins like in southwestern Crimea, a large normal slip rates can generate submarine fault scarps. Part of these fault scarps were affected by submarine erosion before been covered by sediments. Finally, that extensional subsidence was greater than sedimentation rate can explain the two particularities of the Cretaceous sedimentations in Crimea: the stratigraphic onlap on eroded scarps, and the frequent occurrence of limestone olistoliths and olistostromes (Fig. 7D).

\section{4- Tectonic-stratigraphic dating of the extensional deformation in Crimea.}

The examples of the Honcharne and Kyzylove half grabens show that olistoliths and debris flow of Jurassic limestone originate from normal faults scarps. In the Cretaceous of Crimea, the olistoliths do not indicate a compressional setting as it is in many cases in the world (e.g. Golonka et al., 2015). Therefore, occurrence of olistoliths and debris flow in a given stratigraphic units of Crimea provide evidence of contemporaneous extensional faulting. According to Muratov's maps (1969), and Yudin's map (2009), olistoliths are present in the Lower Cretaceous units up to the Albian sandstones. We found olistoliths, olistostromes and limestone debris flow deposits within terrigenous sediments of Valanginian, Hauterivian, Barremian, and Aptian age (Fig. 4B, 5B, 6). Debris flow deposits of Albian age are also reported in the Kadykovsky quarry near Balaklava (Nikishin et al., 2017). Finally, olistoliths and debris flow deposits suggest that normal faulting occurred during the whole Valanginian to Albian period. Note that with the lack of the Upper Berriasian sediments (Nikishin et al., 2017), we cannot exclude that rifting started during the Late Berriasian, immediately before deposition of the Valanginian sediments.

Stratigraphic dating of a tectonic event can also be achieved by determining paleostresses in various stratigraphic units to find out the most recent unit affected by this event. To check if extensional stresses occurred up to the Albian time in Crimea, as suggested by olistoliths we analyzed the rock fractures in a famous outcrop of Albian volcaniclastic sandstones located in a railway trench, $4 \mathrm{~km}$ north from Balaklava (site Volc in Fig. 3). Nikishin et al. (2013) studied this volcaniclastic sandstone from a sedimentology point of view. They defined it as a redeposited andesite-dacite tuff containing fragments of sedimentary rocks and volcanic material up to $1.5 \mathrm{~cm}$ in size (porphyry andesites, plagioclase crystals, clinopyroxene, amphibole...). They interpreted this deposit as a submarine flow that started at an andesite volcanic edifice, and estimated its age by analysis of detrital zircons, at 103+-1 Ma (Late Albian). 
In this outcrop, the layers of volcaniclastic sandstone dip 22 degrees to the northeast (Fig. 8A). At the northern edge of this outcrop, the volcaniclastic unit seems in tectonic contact with thinly bedded sandstones (Fig. 8B). The main fault plane is not exposed, but at proximity, a normal fault cuts and offsets vertically by $50 \mathrm{~cm}$ a layer of Albian volcaniclastic sandstone (Figs. 8B and 8D). Several sedimentary dykes cut the volcaniclastic sandstone (Figs. 8C and 8D), and support the interpretation of syn-Albian extensional faulting. Moreover, the NW-SE trend of the sedimentary dykes and the normal faults is consistent with the NE-SW trend of extension that affected the area during the Early Cretaceous (Figs. 8 and 3).

The Late Albian rocks are the most recent rocks of Crimean Mountains cut by normal faults. We could not map any clear normal faults in Late Cretaceous units. We studied outcrops of Cenomanian to Paleocene rocks to check if normal faulting exists at the small scale, but we only found compressional faults (Table 2). We conclude that in Crimea, the dislocation of the Late Jurassic carbonate platform by extensional tectonic movements started during the Valanginian (or Late Berriasian) and lasted up to Late Albian.

The Late Cretaceous sequence, is devoid of normal faults. The large olistoliths reported on geological maps (e.g. Yudin, 1993; 2009), are present in the Early Cretaceous sequence, but are lacking in the Late Cretaceous sequence (Fig. 3). We conclude that the Valanginian to Late Albian sequence, which was deposited in half grabens and which contains olistoliths and debris flow intercalations, is a syn-rift sequence. In contrast, the Late Cretaceous sequence of Crimea, which is not cut by normal faults and which does not contain olistoliths or debris flow deposits, represents the post-rift sequence.

\section{5- A normal fault array parallel to the crustal structures}

Despite gravitational erosion and successive compressional deformation we could map about ten large normal faults in the Crimean Mountains (Fig. 3). They generally border graben structures and trend NW-SE to WNW-ESE. They are all situated in southwestern Crimea and form an array of parallel normal faults along the southwestern coast of Crimea. The geological map shows that this normal fault array cuts the Early Cretaceous series and their basement, but does not cut the Late Cretaceous sequence, which is the post-rift sequence (Fig. 3).

A $3 \mathrm{D}$ view of the geological map illustrates the structural contrast between the block faulted basement, and the Cenomanian-Cenozoic post-rift sequence (Fig. 9). The graben structures described in the Lower Cretaceous do not exist in the Upper Cretaceous and Cenozoic layers. This view shows that the mapped fault array, with vertical fault displacements of a few hundred meters, is sealed by the Late Cretaceous sequence. This feature denotes thickness variations in the Lower Cretaceous infill, which is typical of synrift sequences. The Late Cretaceous-Paleocene post-rift sequence only shows gentle NW-trending anticlines and synclines. Note that the NW-trending anticline shown in figure 9 probably results from the inversion of a NW-trending normal fault of the basement. This gentle folding probably occurred during the Cenozoic NE-trending compressional event that also reactivated parts of the Honcharne and Kysylove normal faults (Fig. 10A).

Fault kinematic analysis in eight sites along the normal faults, shows that the Early Cretaceous extension was trending NE-SW to NNE-SSW. Given the fact that the mapped array of collinear normal faults formed orthogonal to the least principal stress, we infer that there was no oblique component during rifting in this area.

Structural and paleostress data allow to place the syn-rift/ post-rift boundary at the end of the Albian. This boundary corresponds to a major regional unconformity (e.g. Muratov, 1969: Nikishin et al., 2017). In contrast with other unconformities in the stratigraphic sequence of Crimea, the Albian-Cenomanian unconformity clearly separates the block-faulted basement from the Late Cretaceous post-rift sequence, which was only deformed by Cenozoic shortening events. We interpret it as the break-up unconformity of the Black Sea because it covers the studied normal fault array. 


\section{5- Implications for the geodynamic evolution of the Black Sea Basin}

We showed that large graben structures are present in southwestern Crimea. They trend parallel to the southwestern coast of this peninsula (Fig. 3). This area is the western onshore prolongation of the mid-Black Sea High and the Eastern Black Sea Basin (Fig. 1). It is also located close to the northern continental margin of the Western Black Sea Basin. The fact that the graben structures of Crimea trend parallel to, and are located close to, these Black Sea crustal structures, supports the interpretation that they formed during the rifting of the Black Sea Basin.

A balanced cross section of the southern Black Sea margin showed that, during the rifting of the Black Sea Basin, crustal extension might have taken place via a low-angle mid-crustal detachment to which steeper normal faults connected (Espurt et al., 2014). Similar low-angle detachment faults can be drawn at the northern margin of Western Black Sea Basin (Fig. 1B). A seismic line across the Western Black Sea Basin shows that the basement plunges of $\sim 8 \mathrm{~km}$ along the northern continental margin (Yegorova et al. 2010; Baranova et al., 2011). This high-amplitude normal fault (a in Fig. 1B) was interpreted as a first order rift structure related to the opening of the Western Black Sea Basin (Yegorova et al, 2010). Seismic reflection profiles suggest that it was related to Early Cretaceous normal faulting (Khriachtchevskaia et al., 2009). Moreover, two lowvelocity zones in the upper crust, at the depth of 7-10 and $15 \mathrm{~km}$, were interpreted as zones of major fracturing and porosity (Baranova et al., 2011). We propose that these steep and flat structures may be part of a ramp and flat detachment system associated with the Cretaceous normal faulting (Fig. 1B).

The present northern continental margin of the Western Black Sea Basin was a major ramp of this low-angle detachment fault system (Yegorova et al, 2010). But Cretaceous normal faults have also been inferred in the Scythian Platform from seismic reflection profiles (Fig. 1A; Finetti et al., 1988; Khriachtchevskaia et al., 2010), and in southwestern Crimea from our structural analysis. Flat detachment faults may link these structures (Fig. 1B). The break-away fault of this detachment, that defines the boundary of the Black Sea rift, should be located at the northern margin of the Karkinit Trough (b in Fig. 1B).

It is possible that the low-angle upper-crustal detachment at the northern margin of the Karkinit Trough (b in Fig. 1B) connects with the deeper detachment on the top of the lower crust at the continental margin of the Western Black Sea Basin (a in Fig. 1B). Southward, it can be traced to the crustal base (Moho) of the Western Black Sea Basin, at $20 \mathrm{~km}$ depth. Formation of pairs of localized and conjugate shear zones, one in the upper crust and one in the lower crust-upper mantle, is very typical for the rifting of deep magma poor margins (Lavier and Manatschal, 2006). The Black Sea Basin is one of examples of such deep basins. The processes that weaken the lithosphere during rifting involve attenuation of the upper-middle crust (mid-crustal weakening) in the initial stage of rifting, and serpentinization of the lower crust-upper mantle leading to the formation of detachment surfaces (Lavier and Manatschal, 2006; Péron-Pinvidic and Manatschal, 2009). On figure 1B, the faults mapped in southwestern Crimea can be projected immediately north of fault a.

Our fault kinematic study also provides new information on the geodynamics of the Black Sea Basin. The NE-SW trend of extension, that was determined from inversion of fault slip data, is perpendicular to the main crustal structures of the Black Sea including the mid-Black Sea High, the Eastern Black Sea Basin, the Shatsky ridge, Tuapse trough and the Sinop Trough (Fig. 1). In the central part of the conjugate margin of the Black Sea Basin, in Turkey, the analysis of Cretaceous normal faulting revealed similar graben structures and trends of extension (Fig. 11, 12; Hippolyte et al., 2016). In this area (between Boyabat and Sinop) the main extensional deformation occurred during the Early Cretaceous with the deposition of clastic sediments characterized, like in Crimea, by limestone olistoliths and debris flow intercalations (Fig. 11). That normal block faulting occurred at the same time on the presently separated margins of the Black Sea Basin, and that the trend of extension was normal to the crustal structures of this basin, supports the interpretation that 
the Early Cretaceous normal extension is related to the rifting of the Black Sea Basin (Hippolyte et al., 2010; 2016).

Our stratigraphic and tectonic analyses allow constraining the age of the syn-rift and post rift sequences of this basin. The onset of rifting was characterized by the breakup of the Jurassic carbonate platform (Görür, 1988). Therefore, the syn-rift sequence may include material originating from the faults scarp or from the uplifted flanks of the rift. In northern Turkey, the only Cretaceous stratigraphic sequence that contains olistoliths and clasts of Jurassic limestone is the Early Cretaceous Çağlayan Group, which mainly consists of siliciclastic deposits of Hauterivian-Late Albian age (Fig. 11; Hippolyte et al., 2010). In Crimea, the only Cretaceous series that contain olistoliths and clasts of Jurassic limestone also consists of siliciclastic units of Valanginian to Late Albian age. The siliciclastic material of these similar formations may have been sourced directly by the Ukrainian shield (Okay et al., 2013), or by the erosion of the Triassic-Liassic Tauric flysch, which is present in Crimea (Fig. 2). In both cases, it supports the idea of rift flank uplift and erosion during the Early Cretaceous. Moreover, the Early Cretaceous is the only period characterized by widespread extensional faulting in Crimea (Figs. 4, 5, 6, 7, 8, and 9) and in northern Turkey (Fig. 11). We conclude that there was only one rifting event in the Black Sea area, which occurred from the Valanginian to Late Albian. In northern Turkey, we identified minor extensional deformation postdating the rifting, and occurring from the Santonian to the Paleocene (Hippolyte et al, 2016; 2017). Considering that it characterizes the drifted blocks (present Pontides), we attribute this minor deformation to an extensional state of stress that occurred during and after their drifting.

Major changes in sedimentation occurred along both the southern and northern margins of Black Sea at the proposed syn-rift/post rift transition. They include the end of siliciclastic supply in the Early Cretaceous basins (Görür et al., 1993), and the end of olistolith deposition. Both changes can be explained by the end of block faulting and fault scarp erosion. However, if the source of the Early Cretaceous siliciclastic material was not the Tauric Complex, but directly the East European Craton as proposed by Okay et al. (2013), the first change can also be explained by the onset of drifting which disconnected the Early Cretaceous grabens of Turkey from their northern siliciclastic source. Note that post-rift subsidence and transgression can also be the cause for the end of erosion and siliciclastic supply along the northern Black Sea margin.

In any case, in Crimea, the end of rifting can be dated to the Late Albian by structural analysis. The Albian-Cenomanian unconformity is clearly the break-up unconformity because it separates the block faulted series from the Late Cretaceous sequence. In the Pontides, the major change in sedimentation and the major Cretaceous unconformity are also between the Early Cretaceous siliciclastic sequence and the Late Cretaceous sequence (Görür et al., 1993). Like in Crimea, the Mid-Cretaceous break-up unconformity postdates Early Cretaceous extensional block faulting (Hippolyte et al., 2010; 2016). However, its age cannot be determined as accurately as in Crimea because part of the stratigraphic sequence is missing along this angular unconformity. The fact, Late Cretaceous post-rift subsidence occurred along the southern Black Sea coast, was first noted by Görür et al. (1993). This author dated the break-up unconformity to be Late Cenomanian based on foraminifera. However, nannoplankton assemblages later showed that the uppermost synrift sediments are of Late Albian age (Hippolyte et al., 2010). In the central part of the Turkish coast (Zonguldak area), the onset of deposition of the unconformable post-rift sediments varies from Middle Turonian (Dereköy Formation; Tokay, 1952; Tüysüz et al., 2012) to Coniacian (Kapanboğazı Formation; Ketin and Gümüş 1963; Hippolyte et al., 2010). We believe that the age of the transgression varies because this area was uplifted after a mid-Cretaceous continental accretion (Okay et al., 2006). Anyway, an Albian-Cenomanian age for the break-up unconformity is also compatible with the stratigraphy and structures of the Pontides. In contrast, we could not correlate the Middle Santonian unconformity defined by Tüysüz et al. (2012) with tectonic deformation in Turkey, nor in Crimea. When defined by structural analysis and sedimentary 
changes, the break-up unconformity of the Black Sea Basin occurred clearly between the Albian and the Cenomanian.

The Late Cretaceous drifting probably finished during the Early Campanian, when Cretaceous volcanic activity ended all along the Pontides (Hippolyte et al., 2017), and when subduction jumped to the south of the Anatolide-Tauride-South Armenian microplate at c. $80 \mathrm{Ma}$ (Rolland et al., 2012). If much of the oceanic crust formed from the Early Cenomanian to the Early Campanian, it can explain why there are no magnetic stripes in the Black Sea, as noted by Graham et al. (2013). Oceanic crust may have mainly formed during the abnormally long Cretaceous Superchron (C34) of normal polarity (Aptian to Early Campanian).

In this study, we found that the Black Sea rifting was followed by two main contractional events (Fig. 10). The oldest compression is characterized by its NE-SW trend. A similar trend of compression was identified by Saintot et al. (1998) and correlated to a Late Eocene folding event in the Greater Caucasus. The 3-D view of figure 9 shows that in southwestern Crimea it created a NWtrending gentle anticline. In Crimea, we can date this event because the folded sequence includes the Paleocene and is unconformably overlain by the Eocene (Fig. 3). We infer that the NE-SW compression occurred at the Paleocene-Eocene transition. In the Pontides, the stratigraphic dating of syn-compressional basins and apatite fission-track data showed that contraction related to collisions along the southern margin of Eurasia started during the earliest Eocene at ca. $55 \mathrm{Ma}$. (Kaymakci et al., 2003b, 2009; Hippolyte et al., 2010; Espurt et al., 2014). Therefore, an Early Eocene age for the NE-SW compression and the inversion of the extensional structures mapped in Crimea is compatible with the timing of collisions along the southern margin of Eurasia.

This NE-SW compression can explain offshore structures like a southwestern vergent thrusting or subduction identified within the Western Black Sea Basin (Kaymakci et al., 2014). The southern margin of the mid-Black Sea High might also have been under contraction at this time.

This NE-trending compressional event was followed by NW-trending compressional forces that are still active (Angelier et al., 1994; Saintot et al., 1998; Saintot and Angelier, 2000; Gintov, 2005; Gobarenko et al, 2016; Murovskaya et al, 2016). Some NW-trending normal faults were reactivated with dextral sense like at sites Var2, Gas (Fig. 5A; 7D). We found that at site Geor (Cape Fiolent), the NE-dipping Georgievskyy normal fault (Fig. 3) was also reactivated with a dextral sense (cf. diagram Geor in Fig. 10B). Along this fault, we could observe dextral striations in the Sarmatian (Middle Miocene) limestone, which confirms the recent age of the SE-trending compression (Fig. 10). The Sarmatian marine limestone occurs at more than $1000 \mathrm{~m}$ elevation in the Chatydag Plateau (e.g. Nikishin et al., 2017) which shows that the NW-trending compression is the main shortening event that produced the present Crimean Mountains.

\section{6- Model of Black Sea opening based on fault kinematics}

Our fault kinematic analysis on the two margins of the Black Sea Basin brings new constraints for the models of Black Sea opening. Most of the conceptual models invoke a southward drift of a continental block with sinistral motion along the mid-Black Sea High for opening the Western Black Sea Basin (Robinson et al., 1996; Cloetingh et al., 2003; Yegorova and Gobarenko, 2010; Graham et al., 2013). A NW-SE trend of the Cretaceous extension along the Romanian coast (Hippolyte, 2002) agrees with this direction of opening (Fig. 12). However, the kinematic analyses in Crimea and in Turkey (Hippolyte et al., 2016), indicate NE-SW extension (Figs. 3 and 11). This trend of extension is perpendicular to the southern margin of the mid-Black Sea High. It suggests that rifting was not oblique along the mid-Black Sea High, or along the Sinop Trough. If drifting occurred with the same direction as rifting, this may indicate that there was no sinistral slip along the southern margin of the mid-Black Sea High during the southward opening of Western Black Sea Basin. Although this trend was not predicted by some models for the Western Black Sea Basin, it agrees with the models that invoke a clockwise rotation of the mid-Black Sea High along NEtrending transform faults (e.g. Robinson et al., 1996; Shillington et al., 2009). 
Figure 12 summarizes the trends of extension related to the Early Cretaceous rifting around the Black Sea Basin, the transform faults, and the paleomagnetism data in the Pontides. Under the assumption that drifting occurred in the same direction that rifting, we propose a model of opening that takes into account: (1) the clockwise rotation of the mid-Black Sea High with sinistral transform faults along the eastern border of the Eastern Black Sea Basin (e.g. Robinson et al., 1996; Shillington et al., 2009); (2) the conclusion that there is no transform faults in the middle of the Western Black Sea Basin (Graham et al., 2013); (3) the probable dextral transform faults along the western margin of the Black Sea Basin as proposed by Okay et al. (1994), Robinson et al., (1996) and Nikishin et al. (2003, 2011); (4) the orientations of paleostresses in Crimea and in the Pontides that do not support a strike slip motion along the southern edge of mid-Black Sea High; (5) the differences in extensional stress orientations around the Black Sea Basin (double arrows); (6) the counterclockwise rotation (in the west) and clockwise rotation (in the east) measured from Late Cretaceous rocks along the southern margin of the Black Sea (Meijers et al., 2010a). These block rotations revealed by paleomagnetism studies were interpreted as related to the oroclinal bending of the Central Pontides (Meijers et al., 2010a). But taking into account that: (1) extensional stress field lasted until the Late Paleocene in the Pontides (Hippolyte et al., 2016); (2) there is no rotation detected in the Paleocene or Eocene units (Meijers et al., 2010a), which were deposited before and during the main shortening events (Espurt et al., 2014), (3) ten out of the eleven validated Late Cretaceous paleomagnetic sites are in Coniacian-Santonian rocks; we infer that at least part of the rotations could be related to the Late Cretaceous opening of the Black Sea Basin.

Following the analogue models of asymmetric trench retreat and back arc rift structures of Schellart et al. (2002) and Stephenson and Schellart (2010), we propose that the back arc opening of the Black Sea Basin was driven by two asymmetric slab rollbacks of the Neo-Tethys northward subducting plate. In our model, the clockwise opening of the Eastern Black Sea Basin and the counterclockwise opening of the Western Black Sea Basin (Fig. 12) results from these two asymmetric trench retreats along the southern margin of Eurasia. Transform faults of the Black Sea Basin are only located at the eastern and at the western edges of this basin. Slower slab roll back in the middle of the trench might have been caused by the arrival of asperities in the middle of the retreating subduction zone, like the oceanic volcanic arcs that collided during the Late Albian in the middle of the Pontides (Okay et al., 2006). The wedge-shaped geometry of the western and eastern sub-basins and the concave shape of the Neo-Tethys suture could be partly attributed to this mechanism of back-arc opening (Figs. 1 and 12).

\section{7- Conclusions:}

The Crimean Mountains include a portion of the Black Sea margin that has been inverted during the Cenozoic. Our study provides a new mapping and a fault kinematic analysis of graben structures in Crimea. It is in the western part of the Crimean Mountains that we could map an array of collinear normal faults. These faults trend parallel to the crustal structures of the Black Sea Basin and are situated close to its northern continental margin. Fault chronology indicates that extension predates the Cenozoic shortening events. We confirm that the occurrence of olistoliths and debris flow deposits in Crimea is related to extensional block faulting (e.g. Nikishin et al., 2017). Nannoplankton assemblages from the syn-rift sequence allow the dating of the extensional event to the Valanginian to Late Albian.

On the opposite margin of the Black Sea, in the Pontides, intense extensional faulting, and olistolith emplacement, were also dated of the Early Cretaceous (Hauterivian-Albian; Hippolyte et al., 2016). Given the fact that extensional structures are presents on the two conjugate margins of the Black Sea, and that the trends of extension are normal to the crustal structures, we infer that the Early Cretaceous extension is related to the rifting phase of this basin. This conclusion is also supported by the crustal structure of the Western Black Sea Basin which suggests that the normal faults of Crimea connect to low-angle crustal detachments (Fig. 1B). 
Structural analysis in Crimea reveals a single rifting event. In the Pontides, minor extensional deformation also occurred after the Early Cretaceous rifting. We conclude that the rifting of the Black Sea Basin occurred from the Valanginian to Late Albian, lasted about 39 Ma, and that extensional stresses lasted during Late Cretaceous and Paleocene in the drifted blocks. This age of rifting, based on fault study, is close to some ages proposed based on stratigraphic studies (e.g. Finetti et al., 1988; Görür, 1988; Görür et al., 1993; Okay et al., 1994; Robinson et al., 1995; Nikishin et al., 2008; 2011; Vincent et al., 2016; 2018).

Following Nikishin et al. (2017), we interpret the unconformity between the Albian and the Cenomanian deposits, which separates the faulted terrigenous deposits of Crimea from the nonfaulted Late Cretaceous carbonates, as the break-up unconformity of the Black Sea Basin. In northern Turkey, we also dated the main unconformity in the Cretaceous sequence to latest Albian (Hippolyte et al., 2010; 2017). We infer that this unconformity may also separate the syn-rift sequence from the post-rift sequence in the Black Sea.

Drifting mainly occurred from the Cenomanian to the Early Campanian, contemporaneously with intense volcanic activity along the Pontides volcanic arc in Turkey. The stress pattern of Crimea and Turkey do not confirm a sinistral slip along the southern margin of the mid-Black Sea High during the opening of the Western Black Sea Basin. We propose a model where the Black Sea opened as a consequence of two asymmetric trench retreats of the Neo-Tethys subduction. This model takes into account the transform faults at the western and the eastern margins of the Black Sea Basin, the paleomagnetic data, and the paleostress patterns provided by this study.

Two successive directions of shortening are responsible for the uplift of the Crimean Mountains. The onset of compression is at the Paleocene-Eocene transition, like in the Pontides (Turkey). This coincidence of timing suggests that the compressional deformation along the northern margin of the Black Sea results from the continental collisions that occurred to the south of the Black Sea with transmission of the compressional stresses through the cold lithosphere of the Black Sea Basin (Fig. 1).

\section{Acknowledgements}

Fieldwork started in 2012 with financial support from the DARIUS Programme sponsored by bhpbiliton, BP, CNRS-INSU, ENI, MaerskOil, Petronas Garigali, Shell, Statoil, Total, and the University Paris-6. Special thanks go to Christophe Morhange (CEREGE) for support in the frame of his A*MIDEX-GEOMED project. Therefore, this project received funding from « Excellence Initiative » of Aix Marseille University A*MIDEX (ANR-11-IDEX-0001-02), a french « Investissement d'avenir » program. CEREGE is part of the OSU-Institut Pytheas. We warmly thank Carla Müller for the determination of nannoplankton assemblages. We are grateful to Pr. A. Nikishin and to an anonymous reviewer for their constructive comments. 


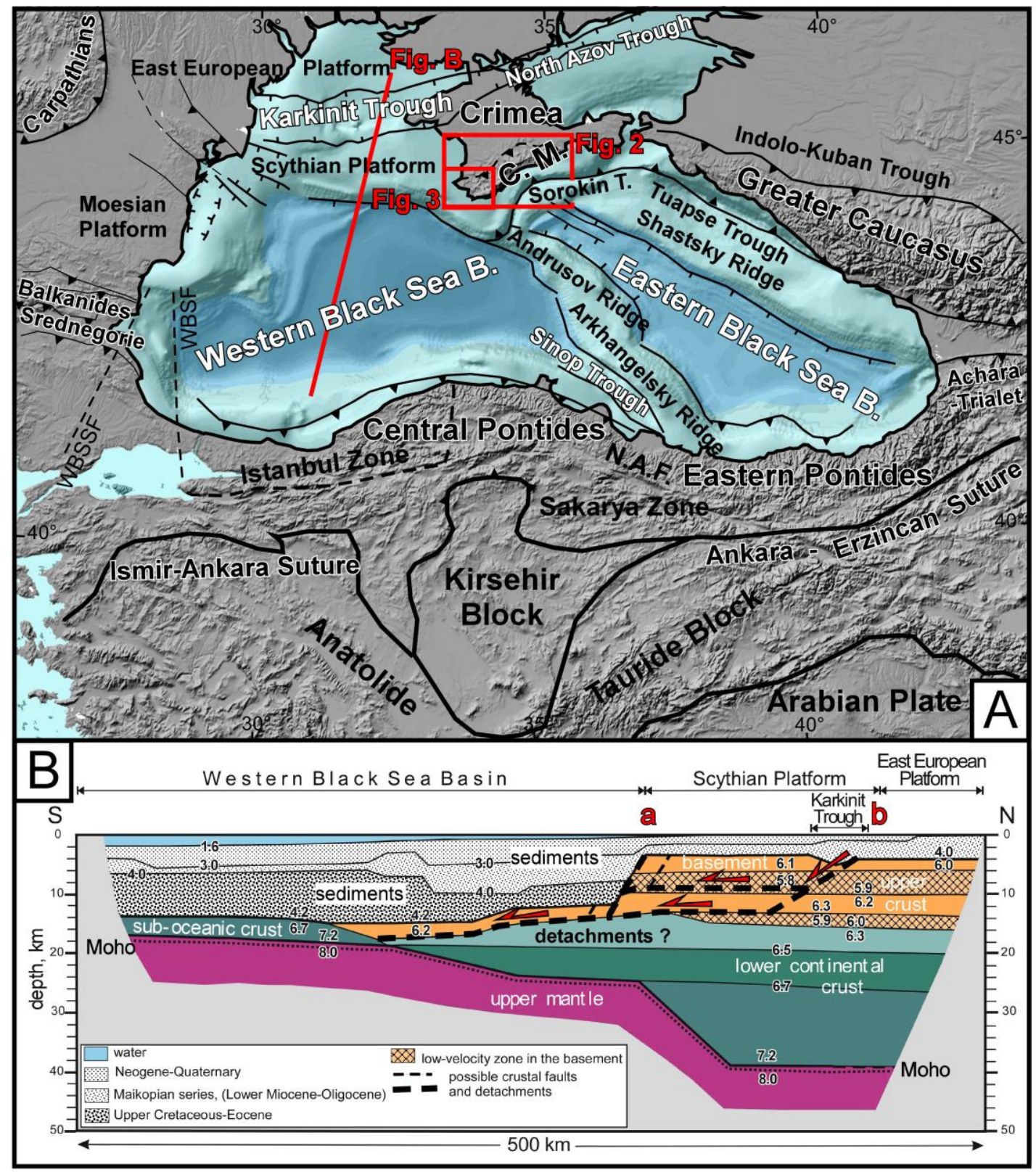

Figure 1: Structural elements of the Black Sea Basin.

A-Shaded relief map of the Black Sea Basin and surrounding mountains with the location of the study area and of the crustal cross-section of figure B. C.M., Crimean Mountains. WBSF, West Black Sea fault (Okay et al., 1994; Robinson et al., 1996). WBSSF, West Black Sea-Saros fault (Nikishin et al., 2003). N.A.F., North Anatolian Fault. The depth map of the Black Sea Basins was realized with the top of Cretaceous depth data of Tugolesov et al. (1985). It shows the structural elements of the Black Sea Basin. The present Black Sea Basin has been produced by the coalescence of two main sub-basins during their postrift phases.

B- Crustal structure of the Western Black Sea Basin, modified from Yegorova et al. (2010) and Baranova et al. (2011) with possible detachment faults. Numbers indicate the modelled velocity in $\mathrm{km} / \mathrm{s}$. (a) main ramp, (b) break-away fault of the detachment.

The Scythian Platform and the East European Platform are characterized by a thick lower crust at the depth 20-40 km, and an upper crust $(V p=6.1-6.3 \mathrm{~km} / \mathrm{s})$ with low-velocity zones (hatched pattern). The Moho, which is at a depth of 18-20 km beneath the Western Black Sea Basin, plunges to the depth of $40 \mathrm{~km}$ beneath the Scythian Plate. Broken lines show the possible low-angle detachments to which the steep normal faults of the northern Black Sea area may connect. 


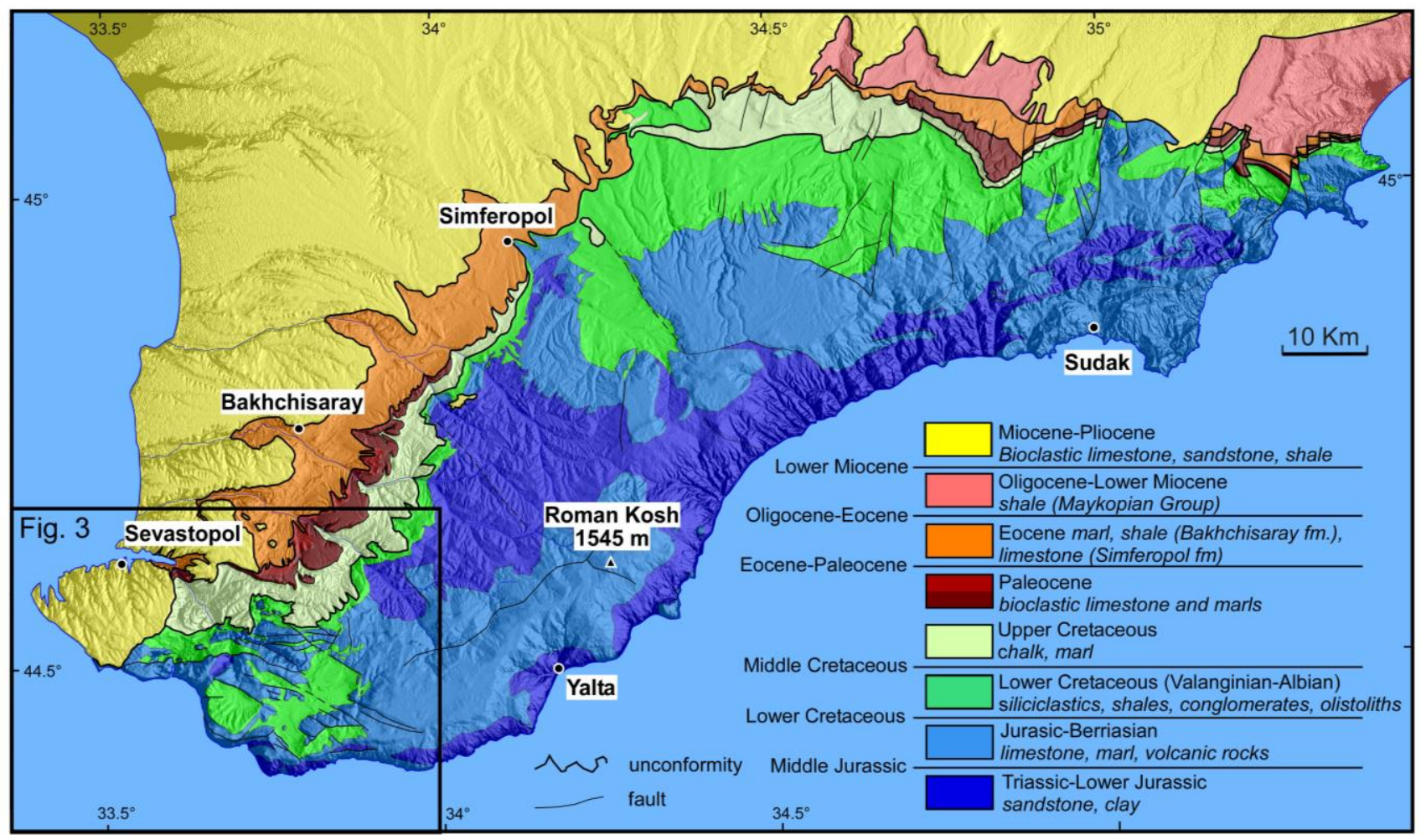

Figure 2: Geological map of Southern Crimea. The contours of formations and the faults are modified from Muratov (1969) and Yudin (2009). Lines in the log show the six main unconformities. The Middle Cretaceous unconformity is the syn-breakup unconformity of the Black Sea Basin. Below this unconformity, the thickness of the Early Cretaceous sequence is variable due to extensional subsidence. The Lower Cretaceous and the Middle Jurassic unconformities are not drawn to better display the faults. 


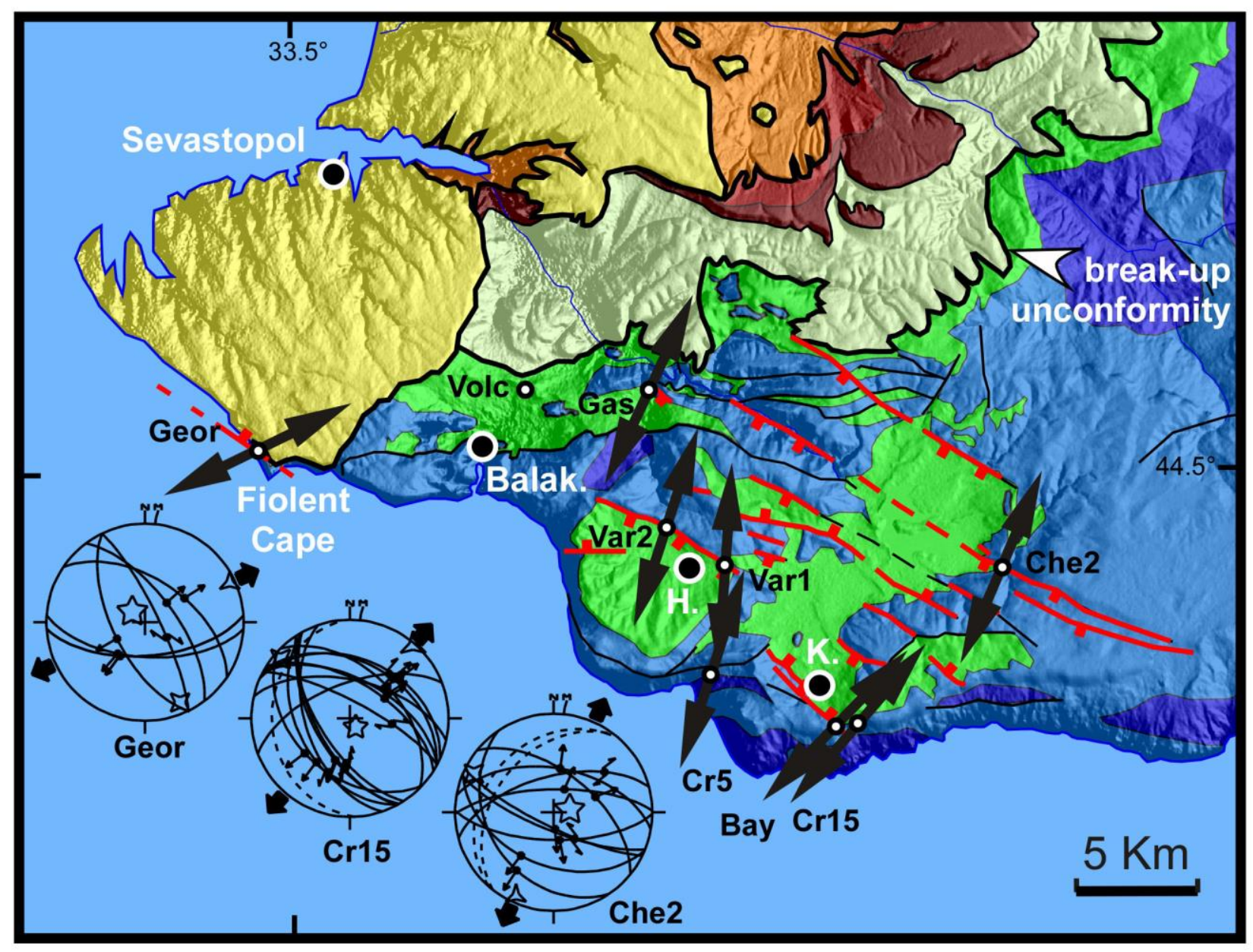

Figure 3: Geological map of southwestern Crimea with in red the normal faults mapped during this work. Lower hemisphere Schmidt's diagrams show examples of normal faults measured at three sites, and the stress axes determined using the INVD stress inversion method (Angelier et al., 1990). Five-branch star $=\sigma 1$ (maximum principal stress axis); four-branch star $=\sigma 2$ (intermediate principal stress axis); threebranch star $=\sigma 3$ (minimum principal stress axis); bedding planes as broken lines. K. Kyzylove village. $H$. Honcharne village. Balak. Balaklava. Name of faults sites in black (see also table 2 and figures 4, 5, 6, 7, 8) 


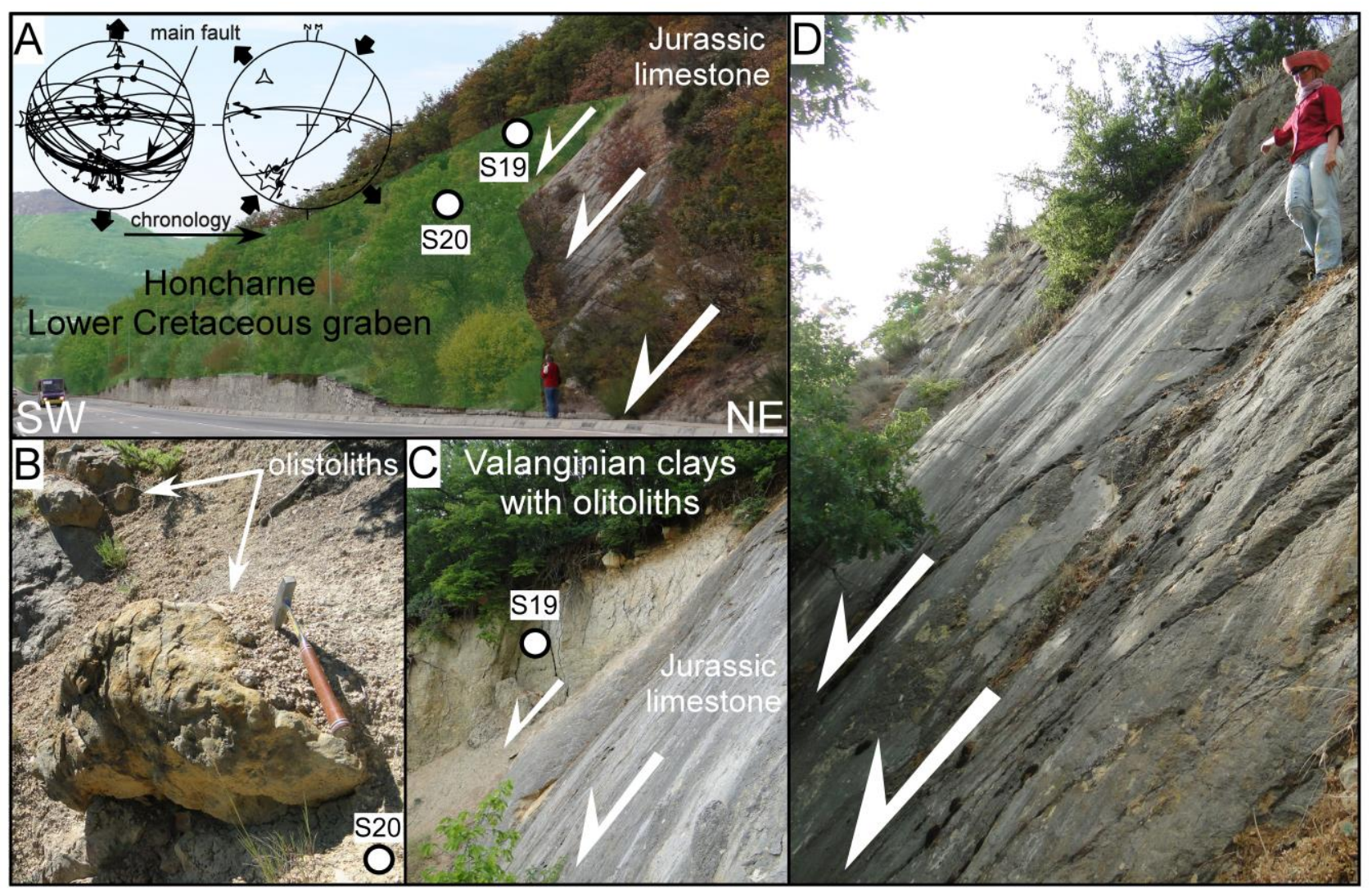

Figure 4: Border fault of the Honcharne half graben at site Var2 (Fig. 3). A: The south-dipping normal fault, between Lower Cretaceous clays of the hanging wall, and Jurassic limestone of the footwall. Samples 19 and 20 contain nannoplankton assemblages of Valanginian age. Lower hemisphere Schmidt's diagrams show the faults measured at this site, and the stress axes determined using the INVD stress inversion method (Angelier et al., 1990). Same legend as figure 3. B: Olistoliths of Jurassic limestone in the Valanginian clays along the fault. C: Fault contact between the Cretaceous clays and the Jurassic limestone. D: Large ridge-and-groove lineations on the fault surface.

Inversion of fault slip data reveals two states of stress: NNE-trending extension and NE-trending compression. Superposition of slickensides on north dipping fault surfaces indicates that the NNE-trending Early Cretaceous extension occurred first. 


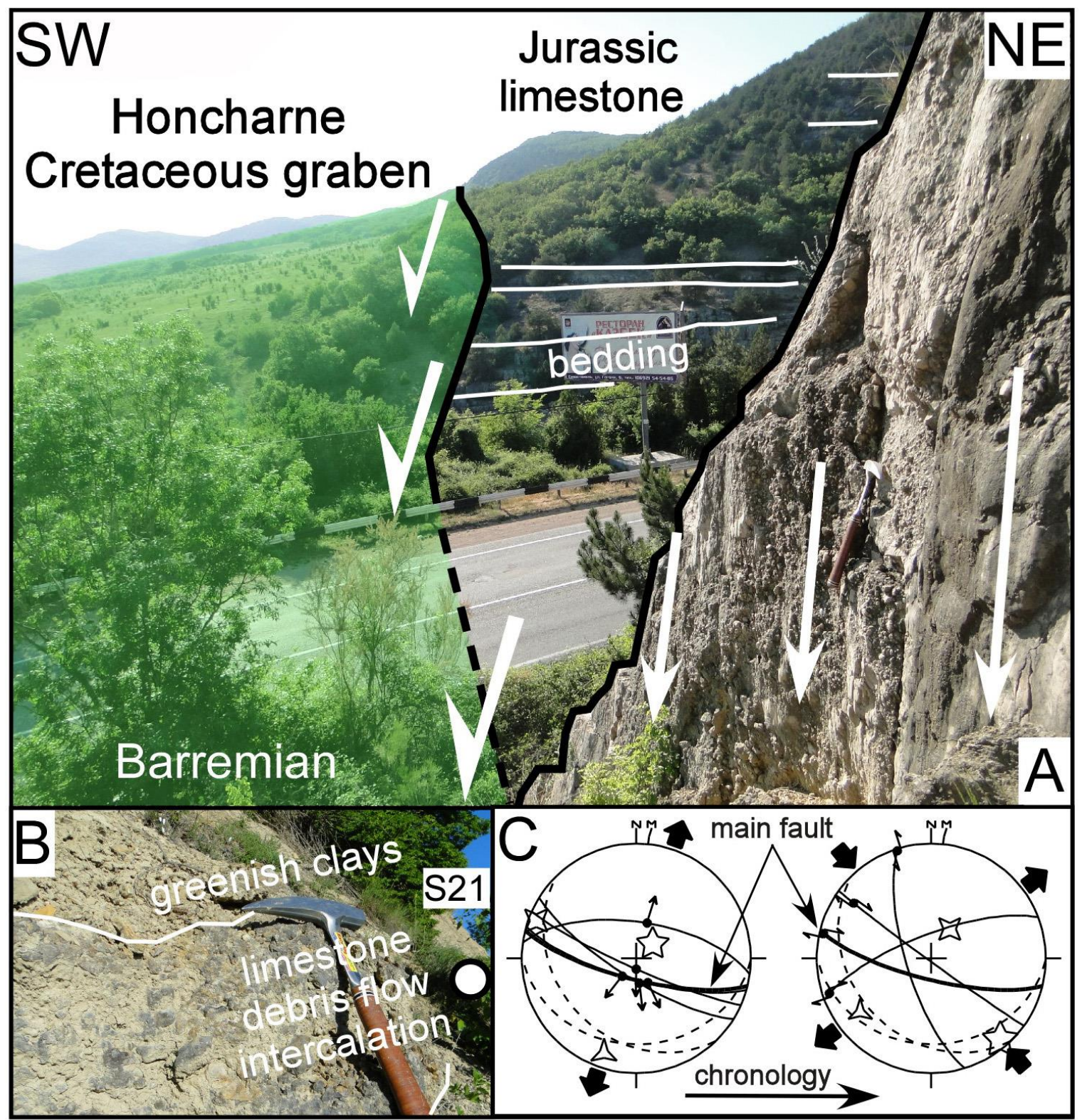

Figure 5: Border fault of the Honcharne half graben at site Varl (Fig. 3). A: The south-dipping normal fault, between Lower Cretaceous clays and Jurassic limestone of the footwall. The fault surface shows large vertical striation, visible in the foreground, and superposed little dextral horizontal striation. B: limestone debris flow intercalation within the Cretaceous clay and sandstones. Sample 21 contains nannoplankton assemblages of Barremian age. C: Fault diagrams (lower hemisphere) show the striated fault surfaces measured at this site and the two successive state of stress: NNE-trending extension followed by SEtrending compression. 


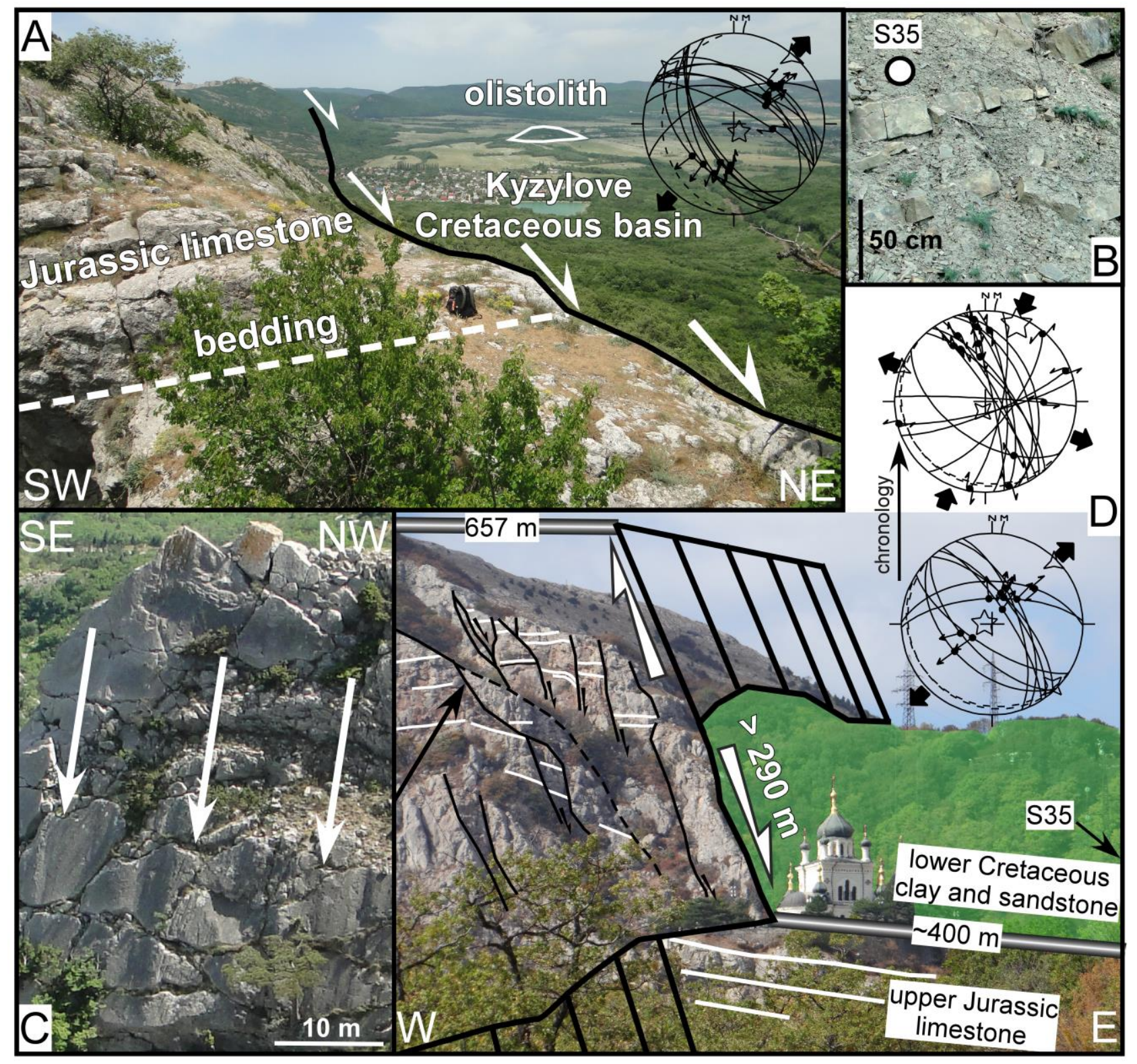

Figure 6: Border fault of the Kyzylove half graben (site Bay in Fig. 3). A: The Kyzylove normal fault between sub-horizontal Jurassic limestones (footwall) and the Lower Cretaceous graben infill. B: Sandstone beds alternating with clays, in the Kyzylove basin. C: Top view of a large striated fault surface in the fault zone shown in figure D. D: Cross-sectional view of the Kyzylove normal fault near Foros church. The church was built at the top of the Jurassic limestone of the hanging-wall block, and the fault displacement is over $290 \mathrm{~m}$. Faults visible in the limestone belong to the fault zone. The two fault diagrams show the fault slips measured in this fault zone. NW-trending faults were reactivated as dextral faults. NE-trending extension was followed by NNE-trending compression. 


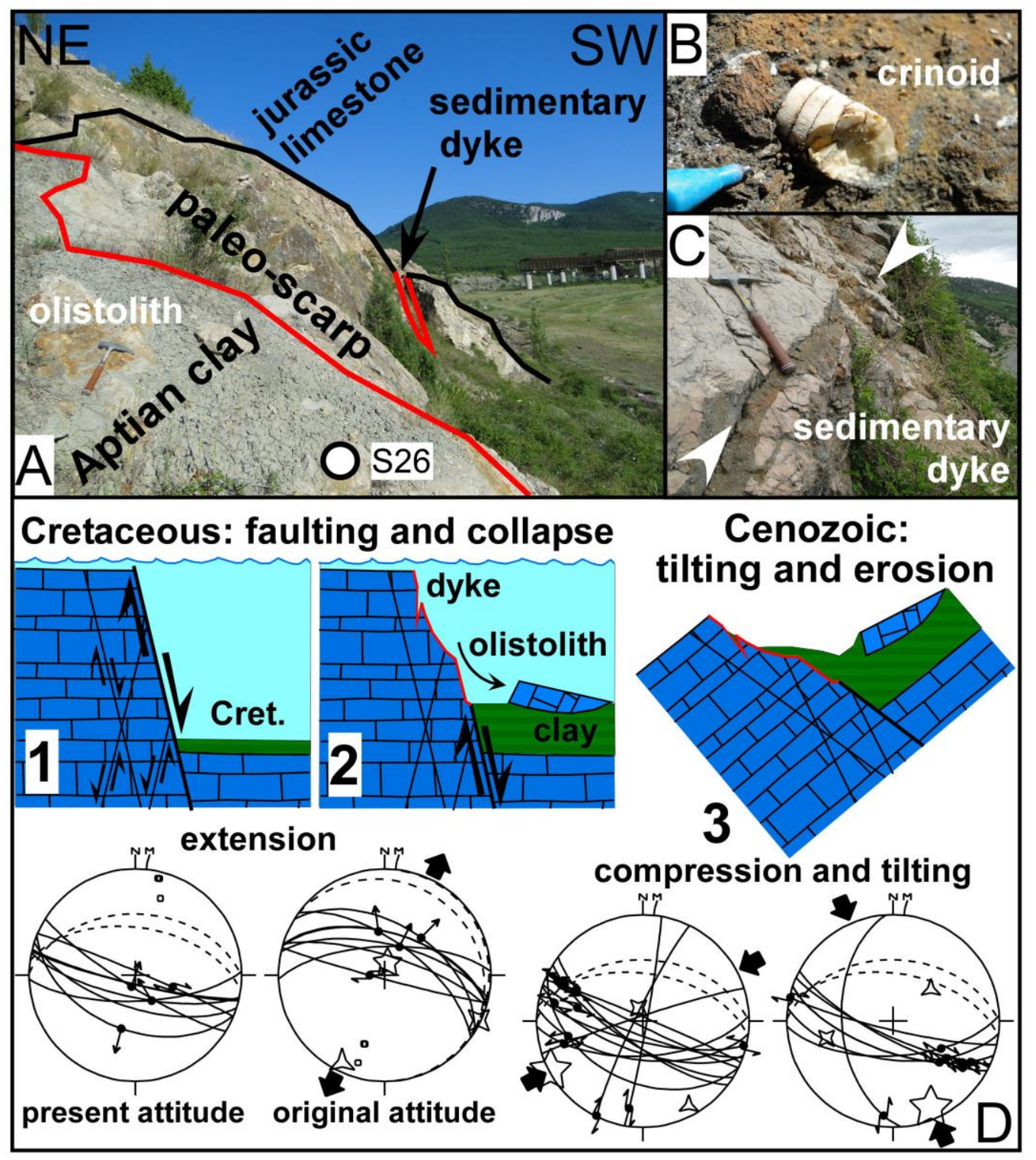

Figure 7: Cretaceous submarine scarp at Gasforta quarry (site Gas in Fig. 3). A: Erosional scarp in the Jurassic limestone, onlapped by Aptian clays (sample 26) that locally also fills sedimentary dykes. The Jurassic limestone dips $40^{\circ}$ to the left (north). The scarp surface is covered by iron oxides with marine fossils. This hardground formed when the scarp was exposed on the seafloor, before deposition of the Aptian clays. B: Detail view of the iron oxide surface showing a fragment of crinoid stem. C: Detail view of a sedimentary dyke filled with Cretaceous sand. D: Model of evolution of the scarp. Step 1: Early Cretaceous, normal faulting. Schmidt's diagrams show the normal faults and sedimentary dykes (dots) in their presentday attitude, and back-tilted to their original attitude (bedding planes as broken lines). In the first diagram, some extensional faults look like reverse faults because they were rotated during folding. Step 2: Early Cretaceous, submarine collapse of the fault scarp producing olistoliths and sedimentary dykes. Step 3: Cenozoic, tilting during two compressional events (NE-SW and NW-SE). Note that many ESE-trending normal faults were reactivates as strike-slip faults. 


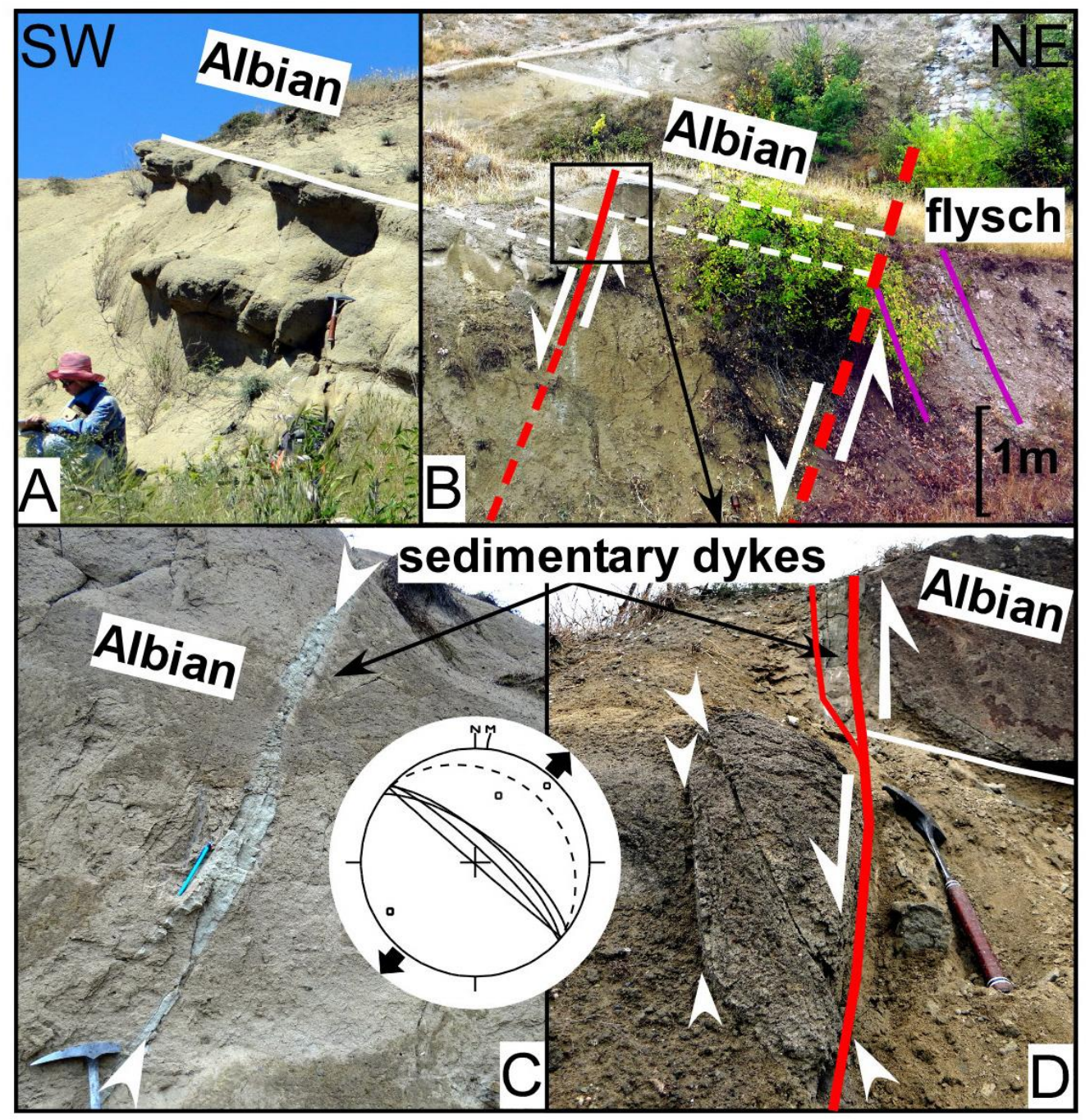

Figure 8: Most recent record of normal faulting: the Late Albian volcaniclastic sandstones of Balaklava. A: Main outcrop of Albian andesite-dacite tuff described by Nikishin et al. (2013). B: Normal faults at the northeastern edge of the outcrop. C: sedimentary dyke in the Albian sandstones. D: Detail view of a fault of figure $B$ with $50 \mathrm{~cm}$ normal offset of a layer, factures and sedimentary dykes in the Albian sandstones. The Schmidt's diagram shows the normal faults (lines) and sedimentary dykes (dots). Their dip directions are close to the NE trend of extension determined in the other sites. 


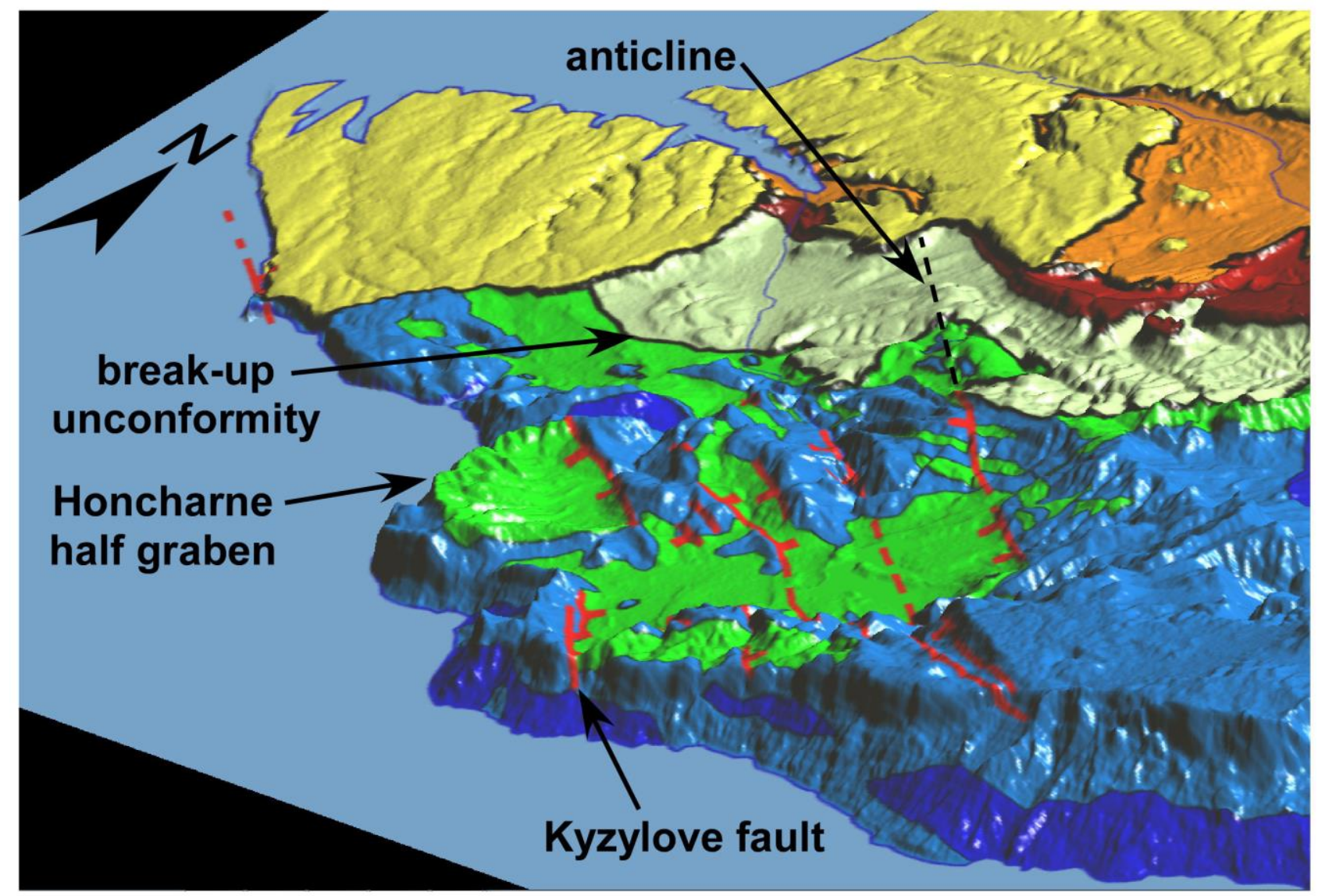

Figure 9: 3D-view of the mapped normal fault array and graben structures. Same color legend as for figure 2. Normal faults and graben structures are only present in rocks older that the Late Cretaceous. The Late Cretaceous post-rift sequence unconformably overlies these structures. Therefore, we interpret the Middle Cretaceous unconformity as the break-up unconformity of the Black Sea Basin. 


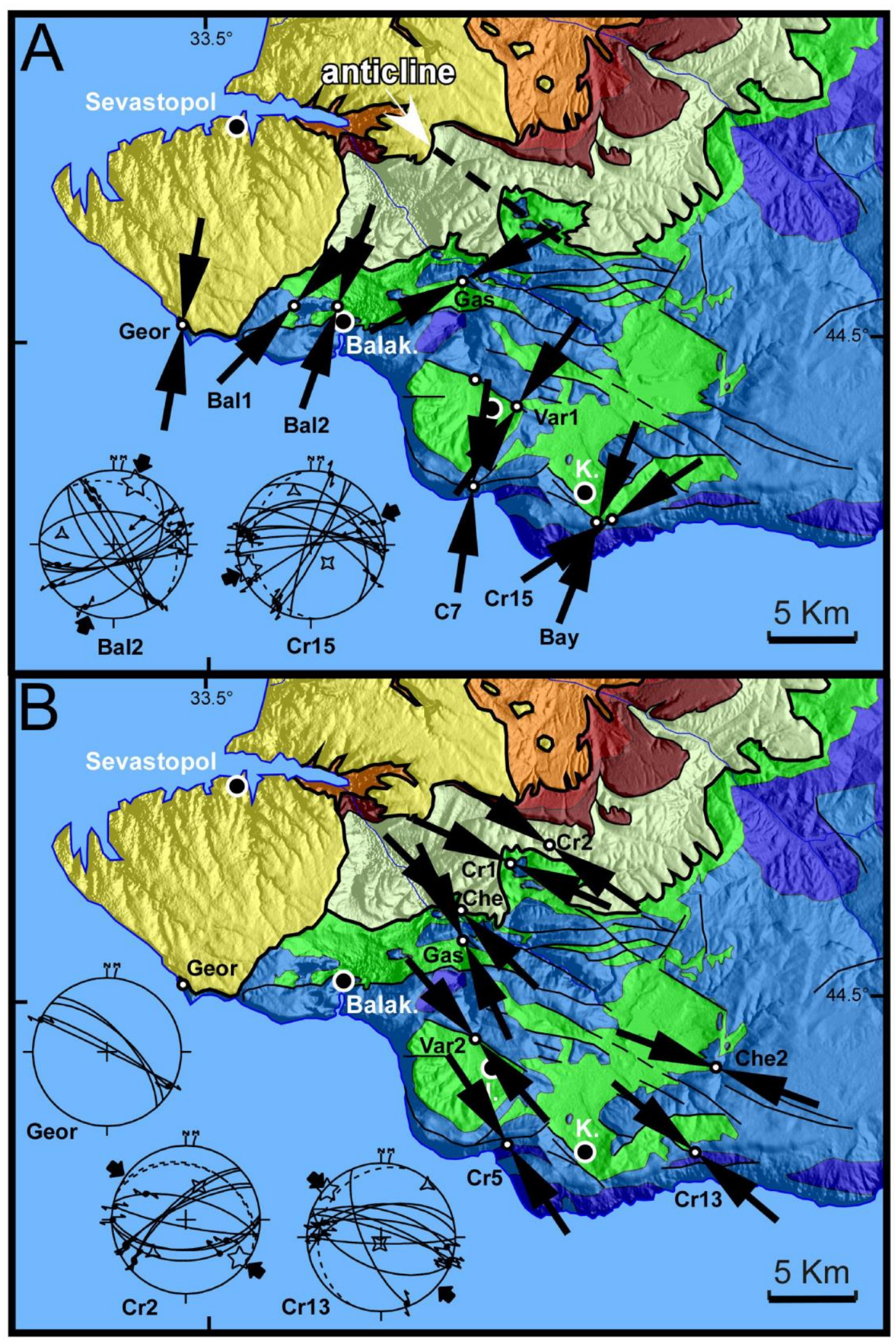

Figure 10: Two successive Cenozoic compressional events in southwestern Crimea (same legend as figure 3). A- Early Eocene NE-trending compression. It partly inverted some normal faults at sites Varnl, Bay and Gas (fig. 4, 7, 6). A NW-trending anticline probably results from the inversion of a normal fault. We infer from the age of the folded sequence that NE-SW compression started at the Paleocene-Eocene transition (c.f. figure 9). B-Eocene to Present SE-trending compression. According to fault chronologies it post-dates the NE-SW compression. 


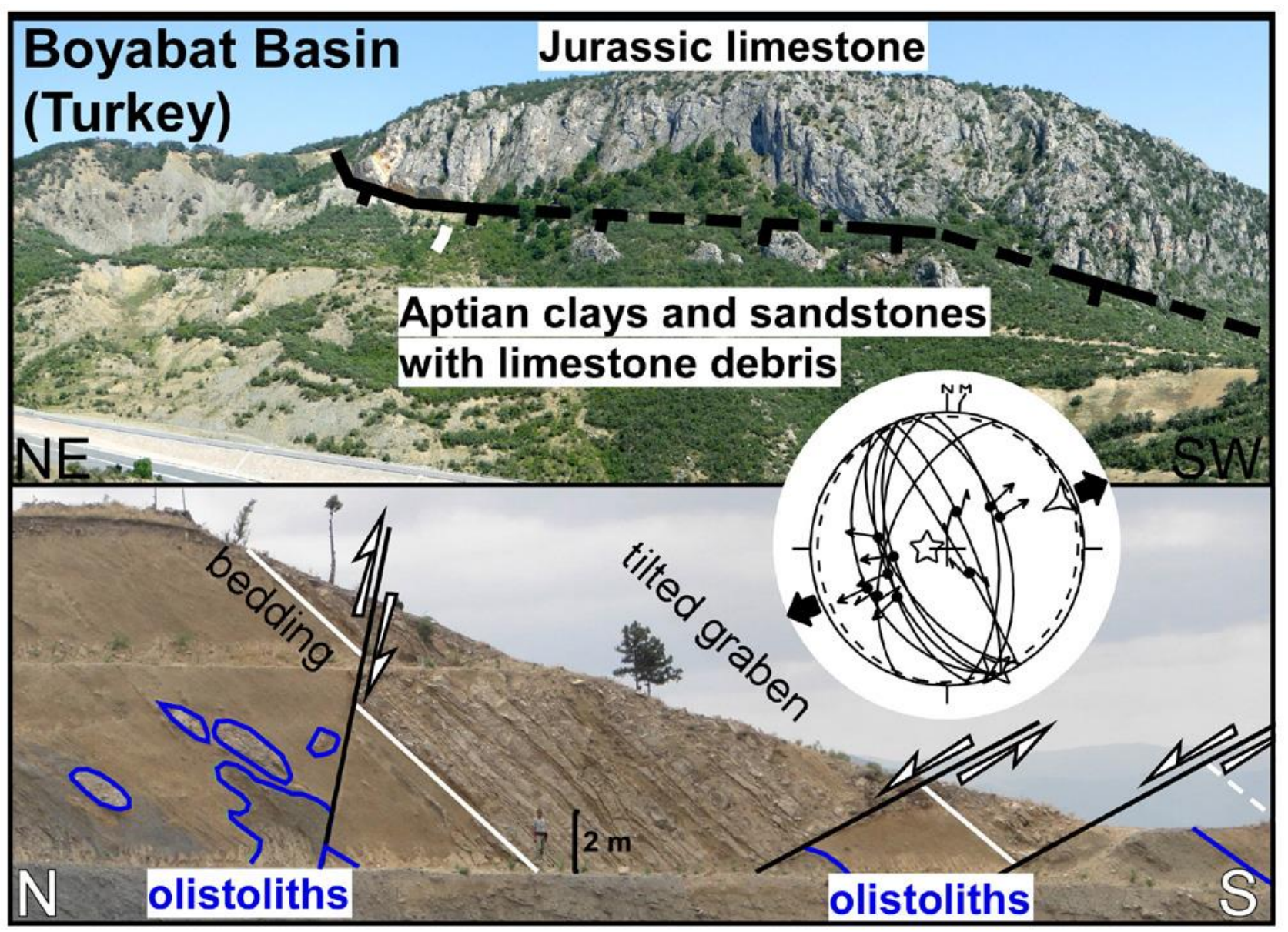

Figure 11: Early Cretaceous graben structures on the opposite margin of the Black Sea Basin in Turkey (Boyabat basin; UTM36 654100E-4604900N, modified from Hippolyte et al., 2016). Like in Crimea, Early Cretaceous graben structures in the Jurassic limestone are filled with clay and sandstones with intercalations of debris flow deposits and olistoliths. Extensional stress was trending NE-SW. 


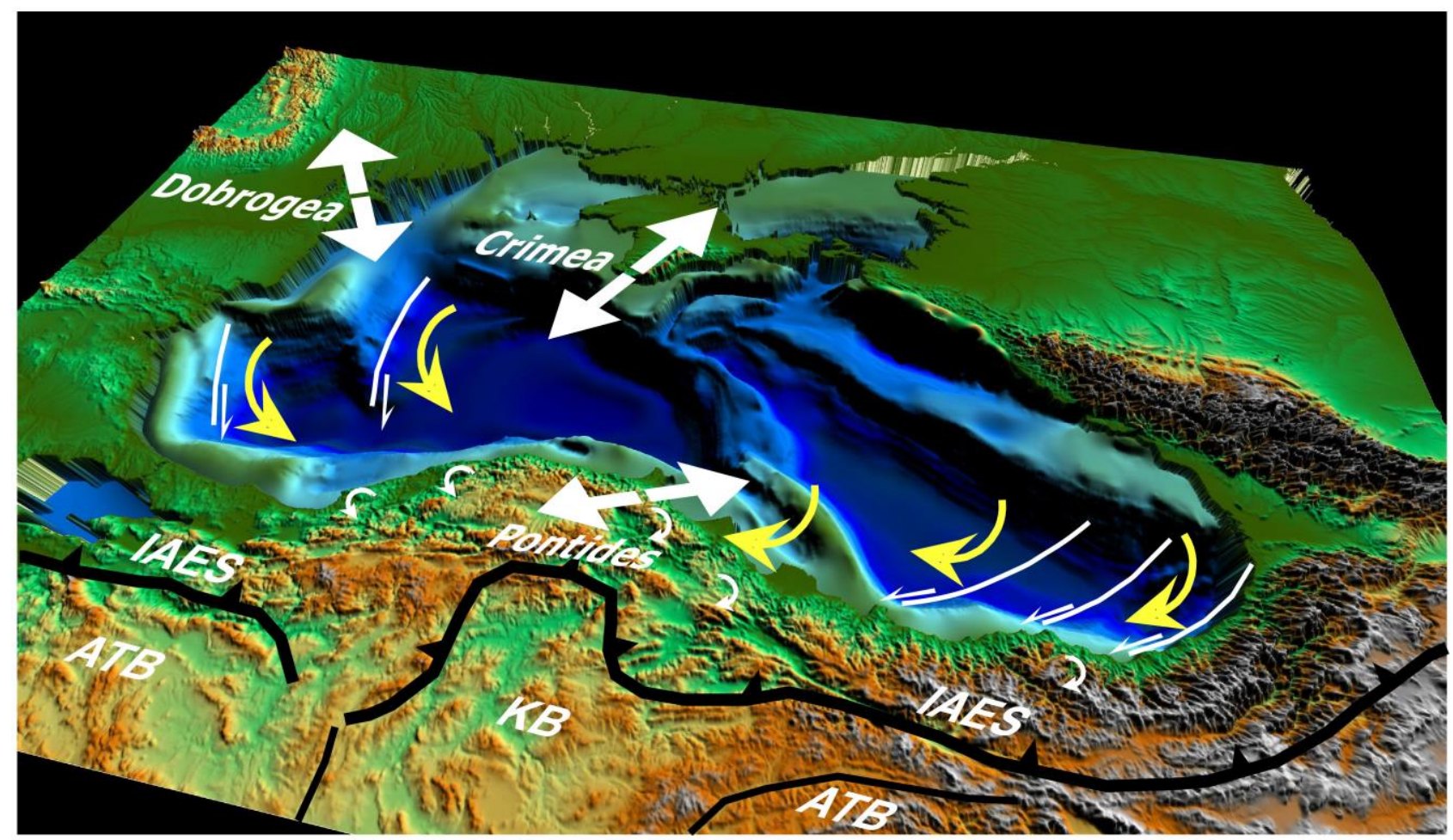

Figure 12: Model of Black Sea opening taking into account the Early Cretaceous trends of extension. We used the top of Cretaceous depth data of Tugolesov et al. (1985) to illustrate the structure of the Black Sea Basin. Double arrows show the trend of extension during rifting from this work, and from Hippolyte (2002) in Romania, and Hippolyte et al. (2016) in Turkey. Small curved arrows in the Pontides show sites where Meijer et al. (2010) measured rotations from Late Cretaceous rocks. Sinistral transform faults in the Eastern Black Sea Basin are from Shillington et al. (2009). The dextral transform fault along the western margin of the Black Sea Basin is the West Black Sea fault (Okay et al., 1994; Robinson et al., 1996). Large curved arrows in yellow indicate the directions of opening. IAES-Izmir-Ankara-Erzincan Suture (modified from Okay and Tüysüz, 1999; Pourteau et al., 2010); KB-Kırşehir block; ATB-Anatolide-Tauride block.

We propose that the Black Sea Basin results from a clockwise opening of the Eastern Black Sea Basin and a counterclockwise opening of the Western Black Sea Basin along transform faults at the eastern and at it western edges. They take into account the paleomagnetism data and syn-rift trends of extension. They are in agreement with the wedge-shaped geometry of the western and eastern sub-basins and the concave shape of the Neo-Tethys suture. The proposed mechanism is for the Valanginian to Early Campanian period. 


\section{Sample name Longitude UTM36 Latitude UTM36 Rock type Age nannofossils}

assemblages

S19 5574834923810 clay Valanginian Watznaueria barnesae, Parhabdolithus embergeri, Ellipsosphaera communis,

Nannoconus colomii, Cruciellipsis cuvillieri, Cyclagelosphaera deflandrei, C. margerelii

S20 5575114923794 clay Valanginian Watznaueria barnesae, Parhabdolithus embergeri, Ellipsosphaera communis,

Nannoconus colomii, Cruciellipsis cuvillieri, Cyclagelosphaera deflandrei, C. margerelii

S21 5551414925340 sandstone and clay Early Barremian Nannoconus colomii, N. kamptnerii, N. steinmannii, Micrantholithus obtusus, Watznaueria barnesae, Ellipsosphaera communis, Parhabdolithus embergeri, Cyclagelosphaera margerelii

S26 5544074931043 clay Late Aptian Nannoconus circularis, Parhabdolithus angustus, Rucinolithus irregularis, Ellipsosphaera communis, Cruciellipsis chiastia

S34 5625644919538 sandy clayand sandstone Upper Aptian Watznaueria barnesae, Parhabdolithus asper, P. embergeri, Nannoconus circularis, Eprolithus floralis, Corronolithin achylosum, Ellipsosphaera communis, Rucinolithus irregularis

S35 5628984917400 sandy clay Valanginian-Hauterivian Watznaueria barnesae, Parhabdolithus embergeri, Ellipsosphaera communis, Nannoconus colomii, Cruciellipsis cuvillieri, Cyclagelosphaera deflandrei, C. margerelii

Table 1: Age and nannoplankton assemblages of the 6 dated samples. Coordinates are in UTM36. Determinations by Carla Müller.

\begin{tabular}{|c|c|c|c|c|c|c|c|c|c|c|c|c|c|c|c|}
\hline \multirow{2}{*}{ Site name } & \multirow{2}{*}{ location } & \multirow{2}{*}{\begin{tabular}{|c|} 
Northing \\
UTM36 \\
\end{tabular}} & \multirow{2}{*}{$\begin{array}{l}\text { Easting } \\
\text { UTMB6 }\end{array}$} & \multirow{2}{*}{ Age of rocks } & \multirow{2}{*}{$\begin{array}{l}\text { stress } \\
\text { regime }\end{array}$} & \multirow{2}{*}{$\begin{array}{c}\text { number of striated } \\
\text { faults }\end{array}$} & \multicolumn{2}{|c|}{$\sigma 1$} & \multicolumn{2}{|c|}{$\sigma 2$} & \multicolumn{2}{|c|}{$\sigma 3$} & \multirow[b]{2}{*}{$\Phi$} & \multirow[b]{2}{*}{ ANG } & \multirow[b]{2}{*}{ RUP } \\
\hline & & & & & & & tr. & pl. & tr. & pl. & tr. & pl. & & & \\
\hline Bal1 & BALA1 & 544676 & 4929606 & Jurassic & $\mathrm{S}$ & 6 & 45 & 16 & 224 & 74 & 315 & 0 & 0,23 & 7 & 18 \\
\hline Bal2 & BALA2 & 547182 & 4929581 & Albian & $\mathrm{S}$ & 12 & 20 & 14 & 132 & 56 & 281 & 30 & 0,06 & 11 & 29 \\
\hline Bay & BAYDAR & 562152 & 4917102 & Jurassic & $E$ & 10 & 275 & 83 & 136 & 5 & 45 & 4 & 0,4 & 11 & 29 \\
\hline Bay & BAYDAR & 562152 & 4917102 & Jurassic & $\mathrm{S}$ & 15 & 22 & 9 & 195 & 81 & 292 & 1 & 0,18 & 10 & 33 \\
\hline Che & CHERNO & 554302 & 4932773 & Cenomanian-Coniacian & $\mathrm{S}$ & 8 & 136 & 6 & 281 & 83 & 45 & 4 & 0,25 & 12 & 50 \\
\hline Che2 & CM18 & 569043 & 4923694 & Jurassic & $\mathrm{E}$ & 9 & 80 & 77 & 296 & 11 & 204 & 8 & 0,31 & 15 & 39 \\
\hline Che2 & CM18 & 555141 & 4923694 & Jurassic & $\mathrm{S}$ & 5 & 291 & 6 & 94 & 83 & 201 & 2 & 0,53 & 19 & 42 \\
\hline $\mathrm{Cr} 1$ & CM1 & \begin{tabular}{|l|}
557173 \\
\end{tabular} & 4935493 & Albian & $\mathrm{C}$ & 12 & 115 & 4 & 207 & 24 & 16 & 65 & 0,44 & 14 & 25 \\
\hline Cr13 & CM13 & 567842 & 4918780 & Jurassic & $\mathrm{s}$ & 9 & 311 & 4 & 192 & 82 & 42 & 7 & 0,27 & 8 & 34 \\
\hline Cr15 & CM15 & \begin{tabular}{|l|}
563057 \\
\end{tabular} & 4917232 & Jurassic & $\mathrm{E}$ & 14 & 147 & 81 & 311 & 8 & 41 & 2 & 0,59 & 4 & 15 \\
\hline Cr15 & CM15 & 563057 & 4917232 & Jurassic & $\mathrm{S}$ & 13 & 248 & 10 & 137 & 63 & 343 & 25 & 0,11 & 9 & 33 \\
\hline $\mathrm{Cr} 2$ & $\mathrm{CM} 2$ & 559415 & 4936561 & Cenomanian-Coniacian & $\mathrm{S}$ & 9 & 126 & 12 & 22 & 50 & 225 & 37 & 0,25 & 16 & 52 \\
\hline $\mathrm{Cr} 5$ & CM5 & \begin{tabular}{|l|}
556965 \\
\end{tabular} & 4919247 & Jurassic & $E$ & 19 & 72 & 70 & 292 & 15 & 199 & 12 & 0,36 & 9 & 24 \\
\hline $\mathrm{Cr} 5$ & CM5 & 556965 & 4919247 & Jurassic & $\mathrm{S}$ & 8 & 327 & 4 & 78 & 79 & 236 & 10 & 0,39 & 12 & 35 \\
\hline $\mathrm{Cr} 7$ & $\mathrm{CM} 7$ & \begin{tabular}{|l|}
555041 \\
\end{tabular} & 4919161 & Jurassic & $\mathrm{C}$ & 10 & 9 & 13 & 276 & 10 & 150 & 73 & 0,54 & 18 & 35 \\
\hline Gas & GASFOR & 554407 & 4931043 & Upper Aptian Sample 26 & $E$ & 4 & 134 & 80 & 116 & 2 & 206 & 9 & 0,47 & 12 & 45 \\
\hline Gas & GASFOR & 554407 & 4931043 & Upper Aptian Sample 26 & $\mathrm{~S}$ & 12 & 242 & 2 & 342 & 80 & 152 & 10 & 0,02 & 13 & 33 \\
\hline Gas & GASFOR & 554407 & 4931043 & Upper Aptian Sample 26 & $\mathrm{~S}$ & 8 & 156 & 12 & 255 & 35 & 50 & 52 & 0,06 & 10 & 27 \\
\hline Geor & GEORGIEV & 538238 & 4928518 & Jurassic & $\mathrm{E}$ & 7 & 310 & 76 & 156 & 12 & 65 & 6 & 0,29 & 11 & 33 \\
\hline Geor & GEORGIEV & 538238 & 4928518 & Jurassic & $\mathrm{s}$ & 10 & 191 & 11 & 63 & 73 & 284 & 13 & 0,59 & 10 & 25 \\
\hline Var1 & VARNAUT1 & 557547 & 4923787 & Valanginian Samples 19-20 & $E$ & 27 & 176 & 76 & 274 & 2 & 5 & 14 & 0,34 & 12 & 31 \\
\hline Var1 & VARNAUT1 & 557547 & 4923787 & Valanginian Samples 19-20 & $\mathrm{S}$ & 4 & 216 & 23 & 90 & 55 & 317 & 25 & 0,26 & 13 & 48 \\
\hline Var2 & VARNAUT2 & 555141 & 4925340 & Lower Barremian Samples 21 & $E$ & 5 & 49 & 74 & 291 & 7 & 199 & 14 & 0,41 & 10 & 31 \\
\hline Var2 & VARNAUT2 & 555141 & 4925340 & Lower Barremian Samples 21 & $\mathrm{~S}$ & 4 & 140 & 8 & 32 & 65 & 233 & 23 & 0,3 & 12 & 41 \\
\hline Volc & VOLC & 549022 & 4931321 & Albian & $E$ & & & & & & & & & & \\
\hline
\end{tabular}

Table 2: Paleostress tensors computed from fault-slip data and coordinates of sites of figures and.

Stress regimes: $C=$ compressional, $S=$ strike-slip, $E=$ extensional. $\sigma 1, \sigma 2, \sigma 3:$ maximum, intermediary and minimum principal stress axis respectively. tr., pl.: trend (north to east) and plunge in ${ }^{\circ}$ of the stress axes. $\Phi$ $=(\sigma 2-\sigma 3) /(\sigma 1-\sigma 3) . A N G=$ average angle between computed shear stress and observed slickenside lineation $\left.{ }^{\circ}\right) . R U P=$ quality estimator $(0 \leq R U P \leq 200)$ taking into account the relative magnitude of the shear stress on fault planes (cf. Angelier, 1990). 


\section{References:}

Adamia, S.A., Chkhotua, T., Kekelia, M., Lordkipanidze, M., Shavishvili, I. and Zakariadze, G., 1981. Tectonics of Caucasus and adjoining regions: implications for the evolution of the Tethys ocean. J. Struct. Geol. 3, 437-447.

Afanasenkov, A. P., Nikishin, A.M. and Obukhov, A.N., 2007. Geology of the Eastern Black Sea. Scientific World, Moscow [in Russian].

Akdoğan R., Okay A.,I., Sunal, G., Tari, G., Meinhold G. and Kylander-Clark, A.R.C., 2017. Provenance of a large Lower Cretaceous turbidite submarine fan complex on the active Laurasian margin: Central Pontides, northern Turkey. Journal of Asian Earth Sciences, 134, 309-329

Angelier, J., 1990. Inversion of field data in fault tectonics to obtain the regional stress-III. A new rapid direct inversion method by analytical means. Geophysical Journal International, 103: 363-376

Angelier, J., Gushtenko, O., Saintot, A., Ilyin, A., Rebetsky, Y., Vassiliev, N., Yakovlev, F. and Malutin, S., 1994. Relationships between stress fields and deformation along a compressive strikeslip belt: Caucasus and Crimea (Russia and Ukraine). Relation entre champs de contraintes et déformations le long d'une chaîne compressive-décrochante: Crimée et Caucase (Russie et Ukraine). C.R. Acad. Sci. Paris, 319, II, 341-348.

Baranova, Y.P., Yegorova, T.P. and Omelchenko, V.D., 2011. Detection of a waveguide in the basement of the northwestern shelf of the Black Sea according to the results of reinterpretation of the DSS materials of profiles 26 and 25 (in Russian), Геофизический журнал (Geophysical journal), 6, 33, 15-29.

Barrier, E. and Vrielynck, B., 2008. Palaeotectonic Map of the Middle East, Atlas of 14 Maps, Tectonosedimentary-Palinspastic Maps from Late Norian to Pliocene. Commission for the Geologic Map of the World (CCMW, CCGM), Paris.

Bektaş, O., Yılmaz, C., Taslı, K., Akdağ, K. and Özgür, S., 1995. Cretaceous rifting of the eastern Pontide carbonate platform (NE Turkey): the formation of carbonates breccias and turbidites as evidences of a drowned platform. Geologia, 57, 1-2, 233-244.

Belousov, V.V., and 24 others, 1988, Structure and evolution of the earth's crust and upper mantle of the Black Sea: Bollettino Di Geofisica Teorica ed Applicata, 30, 109-196.

Bergerat, F., Vangelov, D. and Dimov, D., 2010. Brittle deformation, paleostress field reconstruction and tectonic evolution of the Eastern Blakanides (Bulgaria) during Mesozoic and Cenozoic times. In: Sosson, M., Kaymakci N., Stephenson, R.A., Bergerat, F., Starostenko, V. (eds), Sedimentary Basin Tectonics from the Black Sea and Caucasus to the Arabian Platform. Geological Society London, Special Publication 340: 77-111. DOI: 10.1144/SP340.6

Bilecki, C.B., ed., 2006. Derzhavna gelogichna karta Ukrainy, 1:200 000, arkushi L-36-XXVIII (Eupatoriya), L-36-XXXIV (Sevastopol). Krymska seria (in Ukrainian). Kyiv: Derzhavna Geologiczna Sluzhba «Pivdenekogeocentr».

Cloetingh, S., Spadini, G., Van Wees, J.D. and Beekman, F., 2003. Thermo-mechanical modelling of the Black Sea Basin (de)formation. Sedimentary Geology, 156, 169-184. 
Dercourt, J., Ricou, L.E. and Vrielynck, B. (eds) 1993. Atlas Tethys, Paleoenvironmental Maps. Gauthier-Villars, Paris, 14 maps, 1 plate.

Dercourt, J., Zonenschain, L.P., Ricou, L.E., Kazmin, V.G., Le Pichon, X., Knipper, A.L., Grandjacquet, C., Sbortshikov, I.M., Geyssant, J., Lepvir, C., Pechersky, D.H., Boulin, J., Sibuet, J.-C., Savostin, L.A., Sorokhtin, O., Westphal, M., Bazhenov, M.L., Lauer, J.-P. and Biju-Duval, B., 1986. Geological evolution of the Tethys belt from the Atlantic to the Pamirs since the Lias. Tectonophysics 123, 241-315.

Dinu, C., Wong, H.K., Tambrea, D. and Matenco, L., 2005. Stratigraphic and structural characteristics of the Romanian Black Sea shelf. Tectonophysics, 410, 417-435.

Eren, M. and Tasli, A., 2002. Kilop Cretaceous Hardground (Kale, Gümüshane, NE Turkey): description and origin. Journal of Asian Earth Sciences, 20, 5, 433-448, ISSN 1367-9120, https://doi.org/10.1016/S1367-9120(01)00027-X.

Espurt, N., Hippolyte, J.C., Kaymakci, N. and Sangu, E., 2014. Lithospheric structural control on inversion of the southern margin of the Black Sea Basin, Central Pontides, Turkey. Lithosphere, 6, 1, 26-34, http://doi.org/10.1130/L316.1

Finetti, I., Bricchi, G., Del Ben, A., Pipan, M. and Xuan, Z., 1988. Geophysical study of the Black Sea. Bollettino di Geofisica Teorica ed Applicata, 117-118, 197-324.

Gintov, O.B., 2005. Polevaja tektonofizika i ee primenenie pri izuchenii deformacij zemnoj kory Ukrainy (Field Tectonophysics and its Applications in the Study of Deformations of the Earth's Crust of Ukraine). Kiev: Phoenix. 572 p. (in Russian).

Gobarenko, V.S., Murovskaya, A.V., Yegorova, T.P. and Sheremet, E.E., 2016. Collision processes at the northern margin of the Black Sea. Geotectonics, 50, 4, 407-424.

Golonka, J., Krobicki, M., Waśkowska, A., Cieszkwski, M. and Ślączka, A., 2015. Olistostrome of the Pieniny Klippen Belt, Northern Carpathians. Geol. Mag., 152, 2, 269-286.

Görür, N., 1988. Timing of opening of the Black Sea Basin. Tectonophysics, 147, 247-262

Görür, N., 1997. Cretaceous syn- to post-rift sedimentation on the southern continental margin of the Western Black Sea Basin. In: Robinson, A.G. (ed.), Regional and petroleum geology of the Black Sea and surrounding region. AAPG Memoir, 68, 227-240.

Görür, N., Tüysüz, O., Aykol, A., Sakinc, M., Yigitbas, E. and Akkök, R., 1993. Cretaceous red pelagic carbonates of northern Turkey: Their place in the opening history of the Black Sea. Eclogae Geologicae Helvetiae, 86, 819-838

Gozhik, P.F., Maslun, N.V., Plotnikova, L.F., et al., 2006. Stratigrafiya Mezokainozois'kikh vidkladiv pivnichnozakhidnogo shel'fu Chornogo morya (Stratigraphy of Mesozoic-Cenozoic deposits in the Northwestern Black Sea shelf), Kiiv, Inst. geol. nauk NAN Ukraina

Graham, R., Kaymakci, N. and Horn, B., 2013. Revealing the Mysteries of the Black Sea. GeoExpro, 5, 58-63. 
Hippolyte, J.-C., 2002. Geodynamics of Dobrogea (Romania): new constraints on the evolution of the Tornquist-Teisseyre Line, the Black Sea and the Carpathians. Tectonophysics, 357, 33-53.

Hippolyte, J.-C., Espurt, N., Kaymakci, N., Sangu, E. and Müller, C., 2016. Cross-sectional anatomy and geodynamic evolution of the Central Pontide orogenic belt (northern Turkey). International Journal of Earth Sciences (Geol Rundsch), DOI 10.1007/s00531-015-1170-6, 105, 1, 81-106.

Hippolyte J.-C., Müller, C., Kaymakci, N. and Sangu, E., 2010, Dating of the Black Sea Basin: new nannoplankton ages from its inverted margin in the Central Pontides (Turkey), In Sedimentary Basin Tectonics from the Black Sea and Caucasus to the Arabian Platform, R.A. Stephenson et al., eds., Journal of the Geological Society [London], Special Publications, 340, 113-136, http://doi.org/10.1144/SP340.7

Hippolyte, J.-C, Müller, C., Sangu, E. and Kaymakci, N., 2017. Stratigraphic comparisons along the Pontides (Turkey) based on new nannoplankton age determinations in the Eastern Pontides: geodynamic implications. In: Sosson, M., Stephenson, R. A., Adamia, S. A. (eds), Tectonic Evolution of the Eastern Black Sea and Caucasus. Geological Society, London, Special Publications, 428, 323-358, http://doi.org/10.1144/SP428.9

Hippolyte, J.-C., Murovskaya, A., Müller, C., Volfmann, Y., Yegorova, T., Gintov, O., Sosson, M. and Shemeret, Y., 2014. Preliminary study of Cretaceous normal faulting in western Crimea. Abstract, Final Symposium of Darius Programme, 8-9 December 2014, Paris, France, 66-67.

Kaymakci, N., Duermeijer, C.E., Langereis, C., White, S.H. and van Dijk, P.M., 2003a. Oroclinal bending due to indentation: a paleomagnetic study for the Early Tertiary evolution of the Çankiri Basin (central Anatolia Turkey). Geological Magazine, 140, 343-355.

Kaymakci, N., Graham, R., Bellingham, P. and Horn, B., 2014. Deep structure and tectonics of Black Sea basin inferred from seismic data (BLACKSEA-SPAN). Special Darius publication of final symposium December 8-9, 70-71.

Kaymakci, N., Özcelik, Y., White, S.H. and Van Dijk, P.M., 2009. Tectono-stratigraphy of the Çankiri Basin: Late Cretaceous to Early Miocene evolution of the Neotethyan Suture Zone in Turkey. In: Van Hinsbergen, D.J.J., Edwards, M.A., Govers, R. (eds), Geodynamics of Collision and Collapse at the Africa-Arabia-Eurasia subduction zone, Geological Society of London London Special Issue, 311, 67-106.

Kaymakci, N., White, S.H. and van Dijk, P.M., 2003b. Kinematic and structural development of the Çankiri Basin (Central Anatolia Turkey): a paleostress inversion study. Tectonophysics, 364, 85113.

Ketin, I. and Gümüş, Ö., 1963. Sinop-Ayancik arasindaki III. bölgeye dahil sahalarin jeolojisi hakkinda rapor, 2. Kisim, Jura ve Kretase Formasyonlarinin etüdü. Türkiye Petrolleri Arama Grubu Arsivi (unpublished report), No. 213-288, 118 p.

Khriachtchevskaia, O., Stovba, S. and Popadyuk, I., 2009. Hydrocarbon prospects in the Western Black Sea of Ukraine. The leading Edge, 29, 9, pp. 1024-102à. https://doi.org/10.1190/1.3236371 
Khriachtchevskaia, O., Stovba, S. and Stephenson, R., 2010. Cretaceous-Neogene tectonic evolution of the northern margin of the Black Sea from seismic reflection data and tectonic subsidence analysis. In: Stephenson, R.A. et al. (eds), Sedimentary Basin Tectonics from the Black Sea and Caucasus to the Arabian Platform. Geological Society, London, Special Publications, 340, 137-157 doi:10.1144/SP340.8

Lavier, L. and Manatschal, G., 2006. A mechanism to thin the continental lithosphere at magmapoor margins. Nature, 440, 324-328. doi: 10.1038/nature04608.

Lordkipanidze, M.B., Meliksetian, B. and Djarbashian, R., 1989. Mesozoic-Cenozoic magmatic evolution of the Pontian-Crimean-Caucasian region. In: Raku's, M., Dercourt, J., Nairn, A.E.M. (eds.), IGCP Project No. 198: Evolution of the northern Margin of Tethys. Mém. Soc. géol. France $154,103-124$.

Manetti, P., Boccaletti, M. and Peccerillo, A., 1988. The Black Sea: remnant of a marginal basin behind the Srednegorie-Pontides island arc system during the Upper Cretaceous-Eocene times. Bolletino di Geofisica Teorica ed Applicata, 30, 39-51.

Meijers, M.J.M., Kaymakci, N., Van Hinsbergen, D.J.J., Langereis, C.G., Stephenson, R.A. and Hippolyte, J.-C., 2010a. Late Cretaceous to Paleocene oroclinal bending in the central Pontides (Turkey). Tectonics, 29, TC4016, http://doi.org/:10.1029/2009TC002620.

Meijers, M.J.M., Vrouwe, B., van Hinsbergen, D.J.J., Kuiper, K.F., Wijbrans, J., Davies, G.R., Stephenson, R.A., Kaymakci, N., Matenco, L. and Saintot, A., 2010b. Jurassic arc volcanism on Crimea (Ukraine): implications for the paleo-subduction zone configuration of the Black Sea region. Lithos, 119, 412-426, http://dx.doi.org/10.1016/j.lithos.2010.07.017.

Munteanu, I., Matenco, L., Dinu, C. and Cloetingh, S., 2011. Kinematics of back-arc inversion of the Western Black Sea Basin: Tectonics, 30, TC5004, doi:10.1029/2011TC002865.

Muratov, M.V., 1960. Brief outline of the geological structure of the Crimean peninsula. Gosudarstvenoe nautchno 370 tekhnitcheskoe izdatelstvo literaturi po geologii i okhrane nedr, Moscow 207 p. (in Russian).

Muratov, M.V., (Ed.), 1969. Geology of USSR. Vol VIII. The Crimea. Part 1. Geological Description. Moscow, Nedra, 1969. 576, and Map (in Russian).

Murovskaya, A., Hippolyte, J.-C., Sheremet, E., Egorova, T., Volfman, Yu. and Kolesnikova, E., 2016. Deformation structures and stress field of the south-western Crimea in the context of the evolution of western Black Sea Basin. Geodinamika, 2, 53-68.

Nikishin, A.M., Alekseev, A.S., Baraboshkin, L.F, Kopaevich, L.F., Gabdullin, R.R. and Badulina, N.V., 2008. The Cretaceous history of the Bakhchisaray area, southern Crimea (Ukraine). Bulletin de l'Institut Royal des Sciences Naturelles de Belgique. 78, 75-85.

Nikishin, A.M., Cloetingh, S., Brunet, M.-F., Stephenson, R.A., Bolotov, N. and Ershov, A., 1998. Scythian Platform, Caucasus and Black Sea region: Mesozoic-Cenozoic tectonic history and dynamics. In: Crasquin-Soleau, S., Barrier, E. (eds.), Peri-Tethys Memoir 3: Stratigraphy and Evolution of Peri-Tethyan Platforms. Mém. Muséum national d'Histoire naturelle, Paris, 163-176. 
Nikishin, A.M., Ershov, A.V. and Nikishin, V.A., 2010. Geological history of western Caucasus and adjacent foredeeps based on analysis of the regional balanced section. Dokl. Earth Sci., 430, $155-157$.

Nikishin, A.M., Korotaev, M.V., Ershov, A.V. and Brunet, M.F., 2003. The Black Sea basin: tectonic history and Neogene-Quaternary rapid subsidence modelling. Sedimentary Geology, 156, 149-168.

Nikishin, A.M., Khotylev, A.O., Bychkov, A.Yu., Kopaevich, L.F., Petrov, E.I. and Yapaskurt, V.O., 2013. Cretaceous volcanic belts and the Black Sea Basin history. Moscow University Geology Bulletin, 68, 141-154, http://doi.org/10.3103/S0145875213030058

Nikishin, A.M., Okay, A., Tüysüz, O., Demirer, A., Amelin, N. and Petrov, E., 2015a. The Black Sea basins structure and history: New model based on new deep penetration regional seismic data. Part 1: Basin structure and fill. Marine and petroleum Geology, 59, 638-655.

Nikishin, A.M., Okay, A., Tüysüz, O., Demirer, A., Wannier, M., Amelin, N. and Petrov, E., $2015 b$. The Black Sea basins structure and history: New model based on new deep penetration regional seismic data. Part 2: Tectonic history and paleogeography. Marine and petroleum Geology, 59, 656670.

Nikishin, A.M., Wannier, M., Alekseev, A.S.; Almendiger, O.A.; Fokin, P.A.; Gabdullin, R.R., Khudoley, A.K.; Kopaevich, L.F., Mityukov, A.V., Petrov, E.I., and Rubtsova, E.V., 2017. Mesozoic to recent geological history of southern Crimea and the Eastern Black Sea region. In: Sosson, M., Stephenson, R.A., Adamia, S.A. (eds), Tectonic Evolution of the Eastern Black Sea and Caucasus. Geological Society, London, Special Publications, 428. http://doi.org/10.1144/SP428.1

Nikishin, A.M., Ziegler, P.A., Bolotov, S.N. and Fokin, P.A., 2011. Late Palaeozoic to Cenozoic evolution of the Black Sea-Southern Eastern Europe Region: a view from the Russian Platform. Turkish Journal of Earth Sciences, 20, 571-634, http://doi.org/10.3906/yer-1005-22

Okay, A.I. and Nikishin, A.M., 2015. Tectonic evolution of the southern margin of Laurasia in the Black Sea region. International Geology Review. doi:10.1080/00206814.2015.1010609

Okay, A.I., Şengör, A.M.C. and Görür, N., 1994. Kinematic history of the opening of the Black Sea and its effect on the surrounding regions, Geology, 22, 267-270.

Okay, A.I., Sunal, G., Sherlock, S., Altıner, D., Tüysüz, O., Kylander-Clark, A.R.C. and Aygül, M., 2013, Early Cretaceous sedimentation and orogeny on the active margin of Eurasia: Southern Central Pontides, Turkey. Tectonics, 32, 1-25, doi:10.1002/tect.20077.

Okay, A.I., and Tüysüz, O., 1999. Tethyan Sutures of northern Turkey. In: Durand, B., Jolivet, L, Horvath, F., Séranne, M. (eds), The Mediterranean Basins: Tertiary extension within the Alpine Orogen. Geological Society London, Special Publications, 156, 475-515. doi:10.1144/GSL.SP.1999.156.01.22

Okay, A.I., Tüysüz, O., Satır M., Özkan-Altıner, S., Altıner, D., Sherlock, S. and Eren R.H., 2006. Cretaceous and Triassic subduction-accretion high-pressure-low-temperature metamorphism and continental growth in the Central Pontides Turkey. Geological Society America Bulletin, 118, $1247-1269$ 
Oszczypko, N., Oelyczka, A., Bubniak, I., Olszewska, B. and Garecka, M., 2017. The position and age of flysch deposits in the Crimea Mountains (Southern Ukraine). Geological Quarterly, 61 (X), DOI: http://dx.doi.org/10.7306/gq.1359

Pánek, T. Danišík, M., Hradecký, J. and Frisch, W., 2009. Morpho-tectonic evolution of the Crimean mountains (Ukraine) as constrained by apatite fission track data. Terra Nova, 21, 271-278, doi: 10.1111/j.1365-3121.2009.00881.x

Péron-Pinvidic, G. and Manatschal, G., 2009. The final rifting at deep magma-poor passive margins from Iberia-Newfoundland: a new point of view. Int J Sci (Geol Rundsch), 98, 1581-1597.

Popadyuk, I.V. and Smirnov, S.E., 1991. Problem of the structure of the CrimeanMountains traditional perceptions and reality. Geotectonika, 6, 44-56 (in Russian).

Popadyuk, I.V., Stovba, S.M. and Khriachtchevskaia, O.I., 2013. The New Geological map of the Crimea Mountains by SPK - Geoservice as a new approach to understanding the Black Sea Region. Abstracts of Darius Programme, Eastern Black Sea - Caucasus Workshop, 24-25 June, 2013, Tbilisi, Georgia, 48-50.

Pourteau, A., Candan, O. and Oberhänsli, R., 2010. High-pressure metasediments in central Turkey: Constraints on the Neotethyan closure history. tectonics, 29, TC5004, doi:10.1029/2009TC002650

Robinson, A., Spadini, G., Cloeting, S. and Rudat, J., 1995. Stratigraphic evolution of the Black Sea inferences from basin modeling. Marine and Petroleum Geology, 12, 8, 821-835.

Robinson, A., Rudat, J.H., Banks, C.J. and Wiles, R.L.F., 1996. Petroleum geology of the Black Sea. Marine and Petroleum Geology, 13, 195-223.

Rolland, Y., Perincekb, D., Kaymakci, N., Sosson, M., Barrier, E. and Avagyane, A., 2012. Evidence for $\sim 80-75$ Ma subduction jump during Anatolide-Tauride-Armenian block accretion and $\sim 48$ Ma Arabia-Eurasia collision in Lesser Caucasus-East Anatolia. Journal of Geodynamics, 56-57, 76-85, http://doi.org/:10.1016/j.jog.2011.08.006

Saintot, A. and Angelier, J., 2000. Plio-Quaternary paleostress regimes and relation to structural development in the Kerctch-Taman peninsulas (Ukraine and Russia). Journal of Structural Geology, $22,1049-1064$.

Saintot, A., Angelier, J., Ilyin, A. and Goushtchenko, O., 1998. Reconstruction of paleostress fields in Crimea and the North West Caucasus, relationship with major structures. In: Crasquin-Soleau S., Barrier, E. (eds), Peri-Tethys Memoir 3: stratigraphy and evolution of Peri-Tethyan platforms. Mém. Mus. Natn. Hist. Nat., Paris, 177, 89-112. Paris ISBN: 2-85653-512-7

Saintot, A., Brunet, M.F., Yakovlev, F., Sébrier, M., Stephenson, R., Ershov, A., Chalot-Prat, F. and McCann, T., 2006a. The Mesozoic-Cenozoic tectonic evolution of the Greater Caucasus. In: Gee, D.G., Stephenson R.A. (eds), European Lithosphere Dynamics. Geological Society, London, Memoirs, 32, 277-289. 0435-4052/06/\$15.00 
Saintot, A., Stephenson, R.A., Stovba, S., Brunet, M.F., Yegorova, T. and Starostenko, V., $2006 b$. The evolution of the southern margin of Eastern Europe (Eastern European and Scythian platforms) from the latest Precambrian-Early Palaeozoic to the Early Cretaceous. In: Gee, D.G., Stephenson R.A. (eds), European Lithosphere Dynamics. Geological Society, London, Memoirs, 32, 481-505.

Schellart, W.P., Lister, G.S. and Jessell, M.W., 2002. Analogue modelling of asymmetrical back-arc extension. Journal of the Virtual Explorer, 7, 25-42.

Sheremet, Y, Sosson, M., Muller, C., Gintov, O., Murovskaya, A. and Yegorova, T., 2016a. Key problems of stratigraphy in the Eastern Crimea Peninsula: some insights from new dating and structural data. In: Sosson, M., Stephenson, R.A., Adamia, S.A. (eds), Tectonic Evolution of the Eastern Black Sea and Caucasus. Geological Society, London, Special Publications, 428, http://doi.org/10.1144/SP428.14

Sheremet, Y, Sosson, M., Ratzov, G., Sydorenko, G., Voitsitskiy, Z., Yegorova, T., Gintov, O., Murovskaya, A., 2016b. An offshore-onland transect across the north-eastern Black Sea basin (Crimean margin): Evidence of Paleocene to Pliocene two-stage compression. Tectonophysics, 688, 84-100.

Shillington, D.J., Scott, C.L., Minshull, T.A., Edwards, R.A., Brown, P.J. and White, N., 2009. Abrupt transition from magma-starved to magma-rich rifting in the eastern Black Sea. Geology, 37, 1, 7-10; doi: 10.1130/G25302A.1.

Shillington, D.J., White, N., Minshull, T.A., Edwards, G.R.H., Jones, S.M., Edwards, R.A. and Scott, C.L., 2008, Cenozoic evolution of the eastern Black Sea: a test of depth-dependent stretching models: Earth and Planetary Science Letters, 265, 360-378.

Sosson, M., Stephenson, R., Sheremet, Y., Rolland, Y., Adamia, S.,Melkonian, R., Kangarli, T., Yegorova, T., Avagyan, A., Galoyan, G., Danelian, T., Hässig, M., Meijers, M., Müller, C., Sahakyan, L., Sadradze, N., Alania, V., Enukidze, O. and Mosar, J., 2016. The eastern Black SeaCaucasus region during the Cretaceous: new evidence to constrain its tectonic evolution. Compt. Rendus Geosci. 348, 23-32.

Spadini, G., Robinson, A. and Cloeting, S., 1996. Western versus Eastern Black Sea tectonic evolution: pre-rift lithosphere controls on basin formation. Tectonophysics, 266, 139-154.

Starostenko,V., Buryanov, V., Makarenko, I., Rusakov, O., Stephenson, R., Nikishin, A., Georgiev, G., Gerasimov, M., Dimitriu, R., Legostaeva, O., Pchelarov, V. and Sava, C., 2004. Topography of the crust-mantle boundary beneath the Black Sea Basin: Tectonophysics, 381, 211-233.

Stephenson, R. and Schellart, W.P., 2010. The Black Sea back-arc basin: insights to its origin from geodynamic models of modern analogues. In: Sosson, M., Kaymakci N., Stephenson, R.A., Bergerat, F., Starostenko, V. (eds), Sedimentary Basin Tectonics from the Black Sea and Caucasus to the Arabian Platform. Geological Society London, Special Publication 340, 11-21, doi: $10.1144 / \mathrm{SP} 340.2$

Sydorenko, G., Stephenson, R., Yegorova, T., Starostenko V., Tolkunovi, A., Janik, T., Majdanski, M., Voitsitskiy, Z., Rusakov, O. and Olmelchenko, V., 2017. Geological structure of the northern part of the Eastern Black Sea from regional seismic reflection data including the DOBRE-2 CDP profile. In: Sosson, M., Stephenson, R.A., Adamia, S.A. (eds), Tectonic Evolution of the Eastern 
Black Sea and Caucasus. Geological Society, London, Special Publications, 428, 307-321, http://doi.org/10.1144/SP428.15

Tokay, M., 1952. Contribution à l'étude géologique de la région comprise entre Eregli Alapli Kiziltepe et Alacaağzı. Maden Tetkik ve Arama Enstitüsü Mecmuasi (Mineral Res. and Explor. Inst. Bull.), 42-43, 37-78.

Tugolesov, D.A., Gorshkov, A.S., Meisner L.B. et al., 1985. Tectonics of Mesozoic-Cenozoic Successions of the Black Sea Basin, Nedra, Moscow (in Russian), 215 p.

Tüysüz, O., 1999. Geology of the Cretaceous sedimentary basins of the Western Pontides Geological Journal, 34, 75-93.

Tüysüz, O., 2017. Cretaceous geological evolution of the Pontidesological Society, London, Special Publications, 464, SP464.9, https://doi.org/10.1144/SP464.9

Tüysüz, O., Y1lmaz, I.O., Svábenická, L. and Kirici, S., 2012. The Unaz Formation: a key unit in the Western Black Sea region, N Turkey. Turkish Journal of Earth Sciences 21, 2012-1028

Ustaömer, T. and Robertson, A.H.F., 1994. Late Palaeozoic marginal basin and subductionaccretion: the Palaoetethyan Küre Complex, Central Pontides, northern Turkey. Journal of the Geological Society, London 151, 291-305.

Vincent, S.J., Braham, W., Lavrishchev, V.A., Maynard, J.R.and Harland, M., 2016. The formation and inversion of the western Greater Caucasus Basin and the uplift of the western Greater Caucasus: Implications for the wider Black Sea region. Tectonics, 35, 12, 2948-2962. DOI: 10.1002/2016TC004204

Vincent, S.J., Guo, L., Flecker, R., BouDagher-Fadel, M.K., Ellam, R.M. and Kandemir, R., 2018. Age constraints on intra-formational unconformities in Upper Jurassic-Lower Cretaceous carbonates in northeast Turkey; geodynamic and hydrocarbon implications. Marine and Petroleum Geology. DOI:10.1016/j.marpetgeo.2018.01.011

Vincent, S.J., Morton, A.C., Carter, A., Gibbs, S. and Teimuraz, G., 2007. Oligocene uplift of the Western Greater Caucasus: an effect of initial Arabia-Eurasia collision. Terra Nova 19 (2), 160-166, DOI:10.1111/j.1365-3121.2007.00731.x

Yegorova, T., Baranova, E. and Omelchenko, V., 2010. The crustal structure of the Black Sea from the reinterpretation of deep seismic sounding data acquired in the 1960s, In Sedimentary Basin Tectonics from the Black Sea and Caucasus to the Arabian Platform, R.A. Stephenson et al., eds., Journal of the Geological Society [London], Special Publications, 340, 43-56, doi: $10.1144 /$ SP340.4.

Yegorova, T. and Gobarenko, V., 2010, Structure of the Earth's crust and upper mantle of the Westand East-Black Sea Basins revealed from geophysical data and its tectonic implications, In Sedimentary Basin Tectonics from the Black Sea and Caucasus to the Arabian Platform, R.A. Stephenson et al., eds., Journal of the Geological Society [London], Special Publications, 340, 2342, doi: 10.1144/SP340.3. 
Yegorova, T., Gobarenko, V. and Yanovskaya, T., 2013. Lithosphere structure of the Black Sea from 3-D gravity analysis and seismic tomography. Geophysical Journal International, 193, 287303, http://doi.org/: 10.1093/gji/ggs098

Yudin V.V., 1993. Simferopol mélange. The reports of the Russian Academy of Sciences. 333, 2, 250-252 (In Russian).

Yudin V.V., 2009. Geologicheskaya karta i razrezy Gornogo, Predgornogo Kryma. Masshtab 1 : 200000 [Geologic map and sections of Mountain, Foothill Crimea. Scale 1:200,000]. Krymskaya Akademia Nauk, "Soyuzkarta". Simferopol.

Zonenshain, L.P. and Le Pichon, X., 1986. Deep basins of the Black Sea and Caspian Sea as remnants of Mesozoic back-arc basins, Tectonophysics, 123, 181-211. 